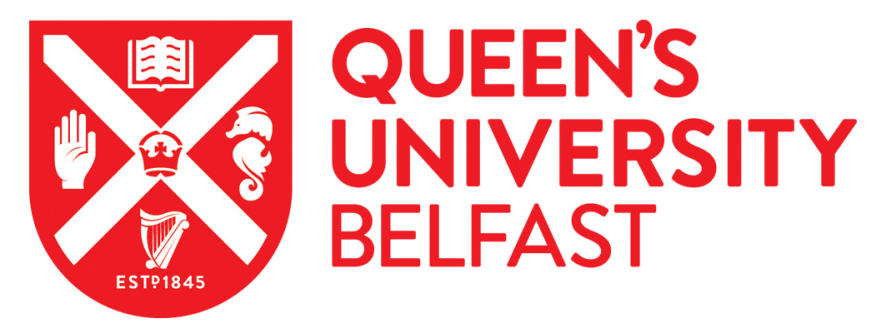

\title{
The Association between Child Maltreatment and Adult Poverty - A Systematic Review of Longitudinal Research
}

\author{
Bunting, L., Davidson, G., McCartan, C., Hanratty, J., Bywaters, P., Mason, W., \& Steils, N. (2018). The \\ Association between Child Maltreatment and Adult Poverty - A Systematic Review of Longitudinal Research. \\ Child abuse \& neglect, 77, 121-133. https://doi.org/10.1016/j.chiabu.2017.12.022
}

Published in:

Child abuse \& neglect

Document Version:

Peer reviewed version

Queen's University Belfast - Research Portal:

Link to publication record in Queen's University Belfast Research Portal

\section{Publisher rights}

Copyright 2017 Elsevier.

This manuscript is distributed under a Creative Commons Attribution-NonCommercial-NoDerivs License

(https://creativecommons.org/licenses/by-nc-nd/4.0/), which permits distribution and reproduction for non-commercial purposes, provided the author and source are cited.

\section{General rights}

Copyright for the publications made accessible via the Queen's University Belfast Research Portal is retained by the author(s) and / or other copyright owners and it is a condition of accessing these publications that users recognise and abide by the legal requirements associated with these rights.

Take down policy

The Research Portal is Queen's institutional repository that provides access to Queen's research output. Every effort has been made to ensure that content in the Research Portal does not infringe any person's rights, or applicable UK laws. If you discover content in the Research Portal that you believe breaches copyright or violates any law, please contact openaccess@qub.ac.uk. 
Title - The Association between Child Maltreatment and Adult Poverty - A Systematic Review of Longitudinal Research

Authors: Lisa Bunting ${ }^{1}$, Gavin Davidson ${ }^{2}$, Claire McCartan ${ }^{3}$, Jennifer Hanratty ${ }^{4}$, Paul Bywaters $^{5}$, Will Mason ${ }^{6}$ and Nicole Steils ${ }^{7}$

${ }^{1}$ Corresponding Author - Lecturer in Social Work, Queen's University Belfast

The School of Sociology, Social Policy and Social Work, 6 College Park, Belfast, United Kingdom, BT7 1LP/ $\underline{\text { l.bunting@qub.a.uk }}$

${ }^{2}$ Senior Lecturer in Social Work, Queen's University Belfast

The School of Sociology, Social Policy and Social Work, 6 College Park, Belfast, United Kingdom, BT7 1LP.g.davidson@qub.ac.uk

${ }^{3}$ Research Assistant, Queen's University Belfast

Institute of Child Care Research, the School of Sociology, Social Policy and Social Work, 6 College Park, Belfast, United Kingdom, BT7 1LP. c.j.mccartan@qub.ac.uk

${ }^{4}$ Research Fellow, Queen's University Belfast

Institute of Child Care Research, the School of Sociology, Social Policy and Social Work, 6 College Park, Belfast, United Kingdom, BT7 1LP. j.hanratty@qub.ac.uk

5 Professor in Social Work Research, Coventry University

Centre for Communities and Social Justice (CCSJ), Coventry University, Priory Street, Coventry, United Kingdom, CV1 5FB. hsx056@coventry.ac.uk

${ }^{6}$ Research Associate, Sheffield University

EImfield Building, Northumberland Road, Sheffield University, United Kingdom. S10 2 TU.

w.j.mason@sheffield.ac.uk

${ }^{7}$ Research Associate, Coventry University

Centre for Communities and Social Justice (CCSJ), Coventry University, Priory Street, Coventry, United Kingdom, CV1 5FB. aa8931@coventry.ac.uk

\section{ACKNOWLEDGEMENTS}

This review was commissioned and funded by the Joseph Rowntree Foundation together with some additional funding from the Nuffield Foundation as part of a larger comparative study 


\title{
Title - The Association between Child Maltreatment and Adult Poverty - A Systematic Review of Longitudinal Research
}

\begin{abstract}
Child maltreatment is a global problem affecting millions of children and is associated with an array of cumulative negative outcomes later in life, including unemployment and financial difficulties. Although establishing child maltreatment as a causal mechanism for adult economic outcomes is fraught with difficulty, understanding the relationship between the two is essential to reducing such inequality. This paper presents findings from a systematic review of longitudinal research examining experiences of child maltreatment and economic outcomes in adulthood. A systematic search of seven databases found twelve eligible retrospective and prospective cohort studies. From the available evidence, there was a relatively clear relationship between 'child maltreatment' and poorer economic outcomes such as reduced income, unemployment, lower level of job skill and fewer assets, over and above the influence of family of origin socio-economic status. Despite an extremely limited evidence base, neglect had a consistent relationship with a number of long-term economic outcomes, while physical abuse has a more consistent relationship with income and employment. Studies examining sexual abuse found less of an association with income and employment, although they did find a relationship to other outcomes such as sickness absence, assets, welfare receipt and financial insecurity. Nonetheless, all twelve studies showed some association between at least one maltreatment type and at least one economic measure. The task for future research is to clarify the relationship between specific maltreatment types and specific economic outcomes, taking account of how this may be influenced by gender and life course stage.
\end{abstract}

Keywords - child maltreatment, childhood adversity, adult economic outcomes, poverty, welfare inequalities, longitudinal, systematic review 


\section{INTRODUCTION}

Estimates of child maltreatment indicate that nearly a quarter of adults $(22.6 \%)$ worldwide have suffered physical abuse as a child, 36.3\% emotional abuse, 16.3\% physical neglect and 11.8\% sexual abuse (Stoltenborgh, Bakermans-Kranenburg, Alink, \& IJzendoorn, 2015). Child characteristics such as gender, age, birth weight and disability and family characteristics such as parental gender, age, psychological functioning, stress, family structure and size have all been identified as factors associated with increased risk of abuse (Krug, Mercy, Dahlberg, \& Zwi, 2002). Numerous studies have also shown a strong association between poverty and child maltreatment (Bagley \& Mallick, 2000; Cawson, Wattam, Brooker, \& Kelly, 2000; Frias-Armenta \& McCloskey, 1998; Hadi, 2000), with higher abuse rates in communities with high levels of unemployment and concentrated poverty.

In the UK, recent research also points to large inequalities in child welfare interventions rates with children living in deprived neighbourhoods being much more likely to be involved in child protection processes or be taken into state care than children living in more affluent neighbourhoods (Bywaters, Brady, Sparks, \& Bos, 2014). A small number of US studies (Cancian, Yang, \& Slack, 2013; Fein \& Lee, 2003; Shook \& Testa, 1997) have also examined variations in family income brought about by changes in social benefits programmes to highlight a causal link between income and involvement with child protection services. For example, Cancian et al. (2013) used data from a randomized experimental evaluation of a state child support program in Wisconsin to show that even very modest income increases (\$100 a month), reduced the risk of a "screened-in" maltreatment report by $10 \%$.

Exposure to child maltreatment is associated with an array of negative outcomes in later life. A growing body of research shows clear and consistent evidence that those exposed to multiple adversities in childhood, including child abuse and neglect, are at increased risk of 
negative psychological, emotional and health-related outcomes in adulthood. This risk is cumulative, with the US Adverse Childhood Experiences (ACE) study (Felitti \& Anda, 2010) reporting a strong, graded relationship between the numbers of childhood adversities experienced and a wide range of negative outcomes. While investigation of the specific relationship between maltreatment in childhood and poverty in adulthood has been more limited, a number of cross-sectional studies have pointed to a strong association between the two [see for example Zielinski (2009) and Barrett, Kamiya, and Sullivan (2014)]. Nonetheless, it remains far from clear to what extent child maltreatment can be considered a causal factor in adult poverty.

Although establishing a causal link is far from easy, developing a better understanding of the relationship between the experience of child maltreatment and subsequent adult poverty is essential to reducing such inequalities. In the hierarchy of research evidence (Elamin \& Montori, 2012) randomised controlled trials are considered the 'gold standard' in terms of establishing a causal link but are invariably not possible in maltreatment research for obvious ethical and legal reasons. While retrospective adult reports of childhood abuse can be used to establish a temporal order in cross sectional, case control and case series research, the risk of recall bias is elevated. There are also concerns that, because participants will already have developed the outcome of interest, those experiencing difficulties may be more inclined to interpret parental behaviors as abusive (Teicher, Samson, Anderson, \& Ohashi, 2016). As such, these study designs are generally viewed as less reliable for establishing causality. Cohort studies, on the other hand, measure the antecedent before the outcome, either prospectively through following participants forward in time, or retrospectively through linkage with existing data which documents the exposure status of participants (Grimes \& Schulz, 2002). Thus, in the absence of evidence from controlled trials, well designed cohort studies are widely considered the most robust means for making causal attributions. 
Although methodological issues related to sample size, representativeness, response rate and attrition are all important factors in reviewing cohort studies, there are additional factors which are especially salient to the assessment of longitudinal maltreatment research. Key amongst these is how maltreatment has been defined and measured. There are no established international definitions of child abuse and neglect and legal definitions can vary both within and between countries (Stoltenborgh et al., 2015). Researchers use diverse standards in determining incidence rates and prevalence in clinical and population-based studies with some focusing on specific abuse types, others conflating abuse types to measure generic constructs of 'child maltreatment' (Petersen, Joseph, \& Feit, 2014). While there is little doubt that exposure to 'maltreatment' poses a significant risk for a range of negative adult outcomes, a growing body of evidence points to differential outcomes, depending on the type or combination of abuse experienced, severity of exposure, and frequency of occurrence (Jackson, Gabrielli, Fleming, Tunno, \& Makanui, 2014). Thus, it is increasingly important that researchers attempt to disentangle these factors from one another in analysis.

Consideration of whether maltreatment data has been collected prospectively or retrospectively also remains a key concern as, even within prospective cohort designs, the measurement of maltreatment exposure may have been conducted retrospectively. In maltreatment research prospective measures that collect data on current or past year exposure at various points during childhood are relatively rare, mainly because of reporting requirements to notify statutory authorities once abuse has been identified (Kendall-Tackett \& Becker-Blease, 2004). As such, prospective maltreatment measures are more commonly based on official records of substantiated maltreatment collected when the child first came to the attention of child welfare professionals. Retrospective measures primarily rely on selfreport data and are usually considered less reliable than prospective measures. However, as Kendall-Tackett and Becker-Blease (2004) note, in the context of maltreatment research 
'researchers should not assume that prospective is "better"'. Child welfare records will only capture a portion of child maltreatment cases which occur within a given population, may be skewed towards more 'serious' cases, may themselves reflect biases in professional decision making and contain missing or incomplete data which do not allow for disaggregation by abuse type. Additionally, the potential for recall bias in retrospective studies may be minimised by the use of validated maltreatment measures which focus on the behaviors experienced by participants as opposed to their own perceptions of abuse, as well as by reducing the period of recall and/or using multiple data collection points or sources to triangulate results.

Given that the literature has shown child maltreatment to be both a cause and consequence of poverty, evaluating how individual studies have controlled for family of origin socioeconomic status (SES) is also extremely important to establishing a causal link between child maltreatment and adult poverty. Indeed, many individual, family, and neighbourhood factors that increase the likelihood of child abuse and neglect are, in turn, associated with adult outcomes (Petersen et al., 2014). In order to disentangle the specific effects of child maltreatment from the effects of other childhood factors, including childhood poverty, consideration needs to be given to how studies have taken account of these potentially confounding factors. In cohort studies, this can be achieved by matching maltreated participants with non-maltreated peers at the design phase or by utilising multivariate statistical techniques which incorporate relevant covariates at the analysis phase.

Taking particular account of these methodological considerations, this systematic review aims to identify the extent to which there is evidence from prospective and retrospective cohort research of a causal association between maltreatment in childhood and poverty in adulthood.

\section{METHODOLOGY}




\section{Review Question}

To what extent is there evidence from longitudinal research of a causal association between maltreatment in childhood and poverty in adulthood?

\section{Search Methods}

A systematic search for empirical research studies was conducted using the databases: Ovid MEDLINE (In-process and other non-indexed citations and from 1946); Embase (Ovid, from 1974); PsycINFO (Ovid, from 1806); Science citation Index and Social Sciences Citation Index (Web of Science); and Econlit (EBSCOhost). Searches were conducted on 24th July 2015 and updated on the 6th May 2017 using the same search strategy (see Supplemental Table 1 for a full list of the search terms used; the review protocol can be accessed at https://www.researchgate.net/project/The-long-term-impact-of-child-abuse-on-adulteconomic-outcomes).

\section{Selection Criteria}

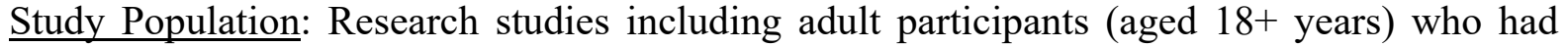
experienced maltreatment before the age of 18 .

Child Maltreatment: Although there are no established international definitions of child abuse and neglect (CAN), the generic term 'child maltreatment' is widely recognised and four main forms of maltreatment commonly identified (Stoltenborgh et al., 2015): child physical abuse (CPA), child sexual abuse (CSA), child emotional abuse (CEA) and/or psychological abuse, and child neglect. Witnessing intimate partner violence is sometimes perceived as not just a risk factor but a form of maltreatment and many reports include other categories or introduce sub-categories. The broad definition of maltreatment outlined above was applied and selected studies had to include at least one measure of physical, sexual or emotional/psychological abuse, neglect, or witnessing domestic violence. 
RUNNING HEAD - Child Maltreatment and Adult Poverty

Outcomes: While recognising that definitions of poverty are often contested (Wolff, Lamb, \& Zur-Szpiro, 2015), the studies included in this review focused primarily on economic related poverty outcomes. As such, measures of income, adult employment, welfare recipiency, or socioeconomic status were identified as the primary outcomes of interest.

Study Design: To be eligible for inclusion in this review, studies had to follow a longitudinal design with data collected at a minimum of two time points and involve statistical comparison of a maltreated group with a non-maltreated group. Case control and case series studies were excluded, as were non-peer-reviewed papers, non-English papers, opinion or editorial pieces and literature reviews. Articles that did not report research findings (e.g., theoretical articles and handbooks) or those that reported qualitative findings were also excluded.

\section{Identification of Relevant Studies}

The search yielded 7,966 records which were retrieved and imported into EndNoteX4 and a further 75 records identified through other sources were added to the database. Duplicates were removed and article titles were screened by one reviewer to remove obviously irrelevant records. The remaining 1,318 records were screened by title and abstract by one reviewer. To ensure consistency a random selection of $10 \%$ of the records was double screened and any disagreements resolved by discussion. The full texts of 84 potentially relevant articles were then retrieved and each assessed by two reviewers against the selection criteria with 13 (reporting on 12 studies) selected for data extraction. Key reasons for exclusion included the study having a cross-sectional or case control design or not including an adult economic measure or child maltreatment measure (see Supplemental Figure 1 for an overview). Additionally, six papers met the inclusion criteria but were excluded as economic measures were analysed as a moderating variable rather than as an outcome variable (see Supplemental Figure 1 for references). A further two papers which 
met the criteria were excluded as the data were reported in other related papers already selected for data extraction (see Supplemental Figure 1 for references).

\section{Data Extraction and Synthesis}

One reviewer (LB) extracted key study details and all data were entered into an MS Excel spreadsheet. This was then checked by $\mathrm{GB}, \mathrm{JH}$ and $\mathrm{CMcC}$ and any disagreements discussed until a consensus was reached. Each study was assessed using Norman, Byambaa, Butchart, Scott and Vos' (2012) assessment of cohort study quality tool. This poses a series of questions about the representativeness of the population, how maltreatment and outcomes were defined and assessed, how non-exposed controls were selected, the adequacy of followup, and the appropriateness of statistical analysis, including methods to control for confounding.

Through the data extraction process, it became clear that both maltreatment and economic outcomes were measured in many different ways and at many different time points. Some studies focused on generic child maltreatment measures, some investigated specific maltreatment types, such as lifetime exposure to CSA or past year exposure to CPA, and others compared different maltreatment types and combinations. The time between baseline and follow up varied from 1-40 years and outcome measures included unemployment, income, disability retirement, homeownership, assets, adult SES and welfare receipt. Due to this heterogeneity, conducting a meta-analysis of the extracted data was not considered appropriate and a narrative synthesis approach instead adopted.

Narrative synthesis refers to an approach to systematic review and synthesis which relies primarily on text to summarise and explain the findings from multiple studies (Ryan, 2013). It involves summarising individual studies, grouping them according to relevant characteristics such as intervention type, population, design, setting or outcomes, and identifying commonalities and differences within and between groups. Studies included in 
this review were grouped according to whether they reported on generic or aggregate child maltreatment or specific maltreatment types. Results from specific maltreatment studies were further subdivided into those which reported on individual abuse types and those which compared multiple abuse types. Relevant methodological issues are described throughout the results section, with particular reference to maltreatment definition and measurement and the use of controls for family of origin SES. The extent to which these factors impact the relationship between maltreatment and economic outcomes and the reliability of results is considered in greater depth in the discussion. Results are reported according to the 'preferred reporting items for systematic reviews and meta-analyses' (PRISMA) guidelines (Moher, Liberati, Tetzlaff and Altman, 2009) [see Supplemental Table 2 for PRISMA checklist].

\section{RESULTS}

The 13 papers that met the review inclusion criteria reported on the findings from 12 studies (as two papers reported on different forms of analysis and abuse grouping using the same research cohort, both have been included). Brief details of the study authors, types of maltreatment examined, outcomes measured and participant age when the data were collected are provided in Tables 1 and 2, together with key statistical findings (a full description of the studies is available in Supplemental Table 3).

Studies were generally of acceptable quality with quality ratings ranging from 5 to 9 on a ten point scale (see Supplemental Table 4 for an overview). Five studies (Fahy, Stansfeld, Smuk, Lain, van der Horst, Vickerstaff \& Clark, 2017; Fergusson, McLeod \& Horwood, 2013; Harkonmäki, Korkeila, Vahtera, Kivimäki, Suominen, Sillanmäki \& Koskenvuo, 2007; Mullen, Martin, Anderson \& Romans, 1994; Mullen, Martin, Anderson, Romans \& Herbison, 1996; Vinnerljung, Sundell, Löfholm, \& Humlesjö, 2006) scored five, five scored six or seven (Covey, Menard \& Franzese, 2013; Lund, Andersen, 
Winding, Biering, \& Labriola, 2013; Pinto Pereira, Li \& Power, 2017; Strøm, Thoresen, Wentzel-Larsena, Hjemdal, Lien \& Dyb, 2013; Tanaka, Jamieson, Duku, Boyle \& MacMillan, 2011) and two scored eight (Currie \& Widom, 2010) or nine (Mersky \& Topitzes, 2010). Study sample size ranged from 492 to 11,874 , with an average of c4250 participants. All studies were conducted in developed nations including North America (4), UK (2), Western Europe (4) and New Zealand (2).

\section{Generic/Aggregated Maltreatment Measures}

Six studies reported on generic maltreatment or aggregated abuse measures with 3 relying on prospective measures using court and/or child welfare agency data (Currie \& Widom, 2010; Mersky \& Topitzes, 2010; Vinnerljung et al., 2006) [see Table 1]. Two of these controlled for family of origin SES by either matching the maltreatment group with a low income group and/or including variables which measured parental education, welfare receipt and employment status in multivariate regression analysis (Currie \& Widom, 2010; Mersky \& Topitzes, 2010). Both these studies showed that substantiated cases of maltreatment decreased employment and reduced income as an adult. Currie \& Widom (2010) also found a relationship between maltreatment and lower level of job skill and fewer assets, such as owning a vehicle or stock. When compared to non-abused women, maltreated women were at greater risk of poorer economic outcomes at age 41, while men were found to be at no greater risk than non-abused men. Comparing children who were referred to child protection authorities and received a service with those referred who did not, Vinnerljung et al. (2006) found that the service group was likely to be in receipt of welfare benefits in early adulthood than the non-service group. However, they were not able to specifically control for family of origin SES and multivariate analysis was limited to those who had come into contact with welfare services during childhood.

\section{Insert Table 1}


RUNNING HEAD - Child Maltreatment and Adult Poverty

The remaining three studies used self-report abuse measures, one when participants were adolescents (Lund et al., 2013) and two when participants were in middle adulthood (Fahy et al., 2017; Harkonmäki et al., 2007). All three showed an increased risk of economic inactivity in adulthood with Lund et al. (2013) highlighting a reduction in employment amongst young adults, Harkonmäki et al. (2007) an increased risk of disability retirement in middle adulthood, and Fahy et al. (2017) an increased risk of being on a permanent sickness or disability pension at age 55 years. Both Lund et al. (2013) and Harkonmäki et al. (2007) used a negative life events scale which included abuse related items and Fahy et al. (2017) used a combined measure covering both sexual and physical abuse. However, only Lund et al. (2013) controlled for family of origin SES, as well as range of additional variables including school grades, educational plans, vocational expectations and health. When added to statistical models the effect of abuse on employment remained significant for females but not males.

\section{Specific Maltreatment Types}

Eight studies reported on specific forms of maltreatment, including two of the studies discussed above (Currie \& Widom, 2010; Fahy et al., 2017) [see Table 2]. All these studies, with the exception of Fahy et al. (2017) controlled for family of origin SES.

\section{$\underline{\text { Insert Table } 2}$}

\section{$\underline{\text { Sexual abuse }}$}

Of the five studies which presented data on CSA, three relied on a single item to identify sexual abuse (Pinto Pereira et al., 2016; Strøm et al., 2013; Tanaka et al., 2011) while two used more detailed questions (Fergusson et al., 2013; Mullen et al., 1994). All studies used retrospective self-report to measure CSA with three collecting data when participants were adolescents or young adults (Fergusson et al., 2013; Strøm et al., 2013; Tanaka et al., 2011), and two when participants were older adults (Mullen et al., 1994; Pinto Pereira et al., 
2016). All studies focused on lifetime exposure to CSA before the age of 16 with the exception of Strøm et al. (2013) who focused on past year exposure. Only Pinto Pereira et al. (2016) specified a perpetrator group in their CSA definition, sexual abuse by parents.

After controlling for family of origin SES, three studies found that CSA was not significantly associated with employment and/or adult income (Fergusson et al., 2013; Strøm et al., 2013; Tanaka et al., 2011), although Tanaka et al. (2011) noted a trend toward reduced employment among females compared to males. Fergusson et al. (2013) examined the relationship between CSA severity and outcomes in linear regression models, controlling for a wide range of covariates including family functioning, child factors and exposure to physical discipline/maltreatment. Gross annual income at age 30 was significantly associated in unadjusted models but became non-significant when covariates were added. Increased welfare dependency when aged 25-30 remained associated, although the effect size was small $(.30)$.

Two studies showed a significant association between CSA and adult economic outcomes. When examined separately from other abuse types and after adjustment for covariates such as parental social class, Pinto Pereira et al. (2016) found that, although CSA was not related to employment, it was associated with greater risk of sickness absence, having less assets, requiring income related support, experiencing financial insecurity and having reduced social class (odds ratios ranged from 1.73-2.98). Similarly, in regression models controlling for family risk factors and exposure to other types of abuse, Mullen et al. (1994) showed an association between CSA amongst females and a decline in adult SES. Mullen et al. (1996) also found a significant relationship between SES and CSA in unadjusted regression models focusing on individual maltreatment types but this relationship became non-significant when additional family risks factors were added.

\section{$\underline{\text { Physical Abuse }}$}


Five studies presented data on CPA. All used self-report to measure maltreatment with two using retrospective measures when participants were young adults (Strøm et al., 2013; Tanaka et al., 2011) and two when participants were older adults (Mullen et al., 1994; Pinto Pereira et al., 2016). Covey et al. (2013) was the only study to prospectively measure CPA through selfreport over five survey waves when participants were aged 11-21 years. Three studies relied on single item measurement covering a range of behaviours such a being beaten, slapped or punched, with two focusing on lifetime exposure to parental CPA (Covey et al., 2013; Pinto Pereira et al., 2016) and one on CPA perpetrated by either youths or adults in the past year (Strøm et al., 2013). Tanaka et al. (2011) used three items to measure exposure to similar acts during childhood but focused on adults as the perpetrator group and used incidence data to differentiate between non-severe CPA and severe-CPA. Mullen et al. $(1994 ; 1996)$ did not give specific details about the number or type of questions used but covered a range of behaviours by parents during childhood, including being beaten (Mullen et al., 1994) or hit with sufficient severity to produce lasting soft tissue injury or require medical attention (Mullen et al., 1996).

Covey et al. (2013) found that having been beaten by a parent was associated with a reduction in income and net worth in middle adulthood but not reduced employment. Strøm et al. (2013) highlighted a relationship between past year CPA and reduced workforce participation amongst young adults, a relationship which remained significant after controlling for high school completion. Likewise, Tanaka et al. (2011) found a relationship between severe CPA and reduced income for young adults as well as and reduced employment for males but not females. These associations were partially mediated by participants' education, physical health, and mental health, although a $29.6 \%$ reduction in annual income still remained. Nonsevere CPA was not associated with either income or employment. 
As with CSA, Pinto Pereira et al. (2016) found that when examined separately from other abuse types, and after controlling for parental social class, those who experienced CPA were at increased risk of sickness absence, unemployment, lack of assets and financial insecurity with odds ratios ranging from 1.52-2.36. Similarly, in unadjusted regression models, both Mullen et al. (1994) and Mullen et al. (1996) found that being beaten as a child was related to a decline in adult socioeconomic status for females. However, after adjusting for family risk factors the relationship became non-significant (Mullen et al., 1996).

\section{$\underline{\text { Neglect }}$}

Three studies investigated the impact of neglect. Currie and Widom (2010) was the only study to use a specific neglect measure based on substantiated child welfare reports. Both Fahy et al. (2017) and Pinto Pereira et al. (2016) conducted secondary analysis of the UK National Child Development Study (1958) and used a prospective measurement of neglect based on parent, teacher or medical examiner reports when participants were aged 7-11 years. Pinto Pereira et al. (2016) used a wider definition which incorporated reports of the child looking undernourished, scruffy or dirty, hardly ever being taken on outings by parents, and parent not showing an interest in their education. Fahy et al. (2017) focused solely on reports of the child looking undernourished, scruffy or dirty.

Currie and Widom (2010) found an association with reduced earnings and employment as well lower level of job skill by middle adulthood and fewer assets such owning a home, a vehicle or stock. Pinto Pereira et al. (2016) also found that, after controlling for parental social class, neglect, by itself, increased the risk of sickness absence, unemployment and lack of assets and reduced social class, with odds ratios ranging from 1.47-1.78. Using the same dataset, but a different measure of neglect, Fahy et al. (2017) found that it was associated with increased risk of being on a permanent sickness or disability pension. Although childhood SES was treated as a separate independent variable in analysis and not controlled 
RUNNING HEAD - Child Maltreatment and Adult Poverty

for in relation to maltreatment, this was not, itself, significantly associated with increased risk of permanent sickness or being on a disability pension.

\section{Emotional/Psychological Abuse}

Two studies investigated the impact of emotional and/or psychological abuse with both relying on retrospective self-report data when participants were older adults (Mullen et al., 1994, 1996; Pinto Pereira et al., 2016). Pinto Pereira et al. (2016) focused on both emotional neglect and psychological abuse, both of which were measured retrospectively when participants were aged 45 years. Emotional neglect was measured by the degree of affection parents showed to the participant and psychological abuse by a positive report that the participant had been verbally abused by a parent.

When considered individually, and after controlling for parental SES, emotional neglect was related to sickness absence, unemployment, lack of assets and financial insecurity, with odds ratios ranging from 1.31-2.34. Similarly psychological abuse, individually, was related to all economic outcomes with the exception of social class, with odds ratios ranging from 1.412.54. Mullen et al. (1994) also identified a relationship between emotional abuse and declining adult SES but in separate regression analysis examining the impact of different abuse types on outcomes, emotional abuse was no longer significantly related (Mullen et al., 1996).

\section{Witnessing Domestic Violence}

Two studies included witnessing violence within analysis: Covey et al. (2013) focused on witnessing parental violence as a child while Pinto Pereira et al. (2016) focused on witnessing the physical or sexual abuse of other family members. Both studies used retrospective selfreport measures collected when participants were adults. Covey et al. (2013) found that witnessing parental violence was related to reduced income and net worth but not unemployment while inconsistently witnessing violence had no association with any of the 
economic outcomes measured. Pinto Pereira et al. (2016) also found that witnessing abuse, when considered individually and after controlling for parental SES, was related to sickness absence, unemployment, lack of assets, income related support and financial insecurity, with odds ratios ranging from 1.47-1.92. However, after controlling for exposure to other abuse types, the results became non-significant.

\section{Comparing Maltreatment Types}

Five studies specifically sought to compare the contribution of different maltreatment types and/or combinations on economic outcomes: one compared CSA and CPA (Tanaka et al., 2011), one compared CSA, CPA and bullying (Strøm et al., 2013); one compared CPA and witnessing violence (Covey et al., 2013); one compared physical, sexual and emotional abuse (Mullen et al., 1996); and one compared neglect, emotional neglect, sexual abuse, physical abuse, psychological abuse and witnessing abuse (Pinto Pereira et al., 2016).

After controlling for exposure to multiple abuse types, Tanaka et al. (2011) found that severe CPA was related to unemployment for males, but not CSA or non-severe CPA. Using various maltreatment combinations, Strøm et al. (2013) found that exposure to both CPA and bullying and both CSA and CPA were associated with reduced workforce participation in young adults while exposure to CPA by itself, both CSA and bullying, and CSA, CPA and bullying, were not. Covey et al. (2013) found that both CPA and consistently witnessing violence were related to reduced income and net worth but that inconsistently witnessing violence was not related to any economic outcomes.

Mullen et al. (1996) found no significant association between maltreatment type and decline in adult SES in separate regression models for sexual, physical and emotional abuse. However, it should be noted that the sample was derived from a community survey on sexual abuse which involved further research with all those respondents who reported CSA together with a random sample of those who had not experienced CSA or extensive CPA. As such, 
analysis extending to other maltreatment types may not adequately reflect their distribution in the general population. Equally, Mullen et al. $(1994,1996)$ involved relatively small numbers $(\mathrm{n}=492)$ and in Mullen et al. (1996) more stringent maltreatment definitions were used, effectively halving the number of participants in the maltreatment group and reducing the power of the study to detect significant differences between maltreatment types and associated outcomes.

Pinto Pereira et al. (2016) examined the impact of a broad range of maltreatment types, both individually and in regression models which controlled for exposure to multiple abuse types. Individually, each maltreatment types was associated with at least four of the six economic outcomes measured and although patterns varied somewhat, all were significantly associated with sickness absence and lack of assets. When all maltreatment types were considered simultaneously associations with 50-year outcomes were reduced. In simultaneous models physical abuse and witnessing abuse were no longer associated with any outcomes; emotional abuse only remained associated with financial insecurity; psychological abuse remained associated with a range of outcomes but at much lower levels with odds ratios ranging from 1.28-1.41. Neglect and sexual abuse maintained the strongest relationships: CSA remained related to sickness absence, income support, financial insecurity and social class, with odds ratios ranging from $1.73-1.92$; neglect remained related to sickness absence, unemployment lack of assets and social class, with odds ratios ranging 1.42-1.77.

\section{DISCUSSION}

Despite the variation in populations studied, the majority of studies demonstrated a significant association between a history of childhood maltreatment and at least one adult economic measure. Studies using generic or aggregated maltreatment measures, based on both prospectively collected data from official records and self-reported retrospective data, all found associations with increased economic inactivity and/or reduced income. Two studies, 
in particular, provided strong evidence of a causal connection between coming into contact with child welfare agencies because of abuse concerns and subsequent economic impact in later life (Currie \& Widom, 2010; Mersky \& Topitzes, 2010). Through controlling for parental education, employment and benefit receipt, Currie and Widom (2010) and Mersky and Topzites (2010) were able to show that generic child maltreatment experiences make an independent contribution to adult economic outcomes, over and above those associated with these common indicators of social disadvantage. In relation to income, Currie and Widom (2010) reported that, by middle adulthood, maltreated individuals earned $\$ 8,000$ less per year, while Mersky and Topzites (2010) identified a 34\% reduction in income for young adults.

However, many of the limitations of utilising prospective child welfare data apply to these findings. With the exception of neglect, neither study was able to differentiate between maltreatment types. Although both attempted to account for variations in professional decision making by focusing on substantiated or indicated maltreatment cases, this introduced other limitations. These are exemplified by Vinnerljung et al.'s (2006) study, which compared outcomes for children who had been referred to child welfare agencies and received a service (substantiated cases) with those referred but who had not received a service (unsubstantiated cases). Although the service group were at greater risk of negative adult outcomes than the non-service group, the outcomes for the both groups were markedly similar and considerably worse than general population peers. The authors postulated that the substantiation process may not have sufficiently discriminated between serious and less serious child maltreatment cases and recommended inclusion of both case types in future follow up studies.

In addition to aggregated child maltreatment measures, eight studies reported on findings related to specific maltreatment types. While much of these data were derived retrospectively it is worth noting one of the key issues surrounding memory recall bias in retrospective designs concerns negative attribution increasing the risk of false positives. However, this 
concern is not borne out in the literature with studies comparing retrospective and prospective maltreatment assessment showing that retrospective reports tend to produce lower rather than higher rates than prospective designs (Teicher et al., 2016). Given the limits of official records and the ethical difficulties associated with prospective maltreatment measurement, studies using retrospective reports provide valuable information on a population of adult survivors often missed in prospective designs (Kendall-Tackett \& Becker-Blease, 2004). Additionally, four of the eight retrospective studies included in this review minimised the potential for bias by measuring abuse exposure when participants were adolescents or young adults (Covey et al., 2013; Fergusson et al., 2013; Strøm et al., 2013; Tanaka et al., 2011).

Surprisingly, despite being the most common form of abuse in many Western countries, only three studies included a measure of neglect (Currie \& Widom, 2010; Fahy et al., 2017; Pinto Pereira et al., 2016). Nonetheless, all three showed a significant association with a wide range of economic outcomes and, in comparison with other abuse types, neglect was found to have a similar magnitude of effect as sexual abuse (Pinto Pereira et al., 2016). Even fewer studies included emotional/psychological abuse or witnessing violence/abuse and the results were less conclusive (Covey et al., 2013; Mullen et al., 1994; Pinto Pereira et al., 2016). The relationship between emotional/psychological abuse and outcomes tended to disappear when exposure to other maltreatment types and family risk factors were include in analysis. This suggests that while emotional abuse, by itself, can contribute to negative outcomes, when it is comorbid with other maltreatment, it is the other maltreatment types which carry greater weight in terms of predicting economic outcomes. In one study (Pinto Pereiro et al., 2016), witnessing abuse showed a similar pattern of association at an individual level but reduced effect when controlling for other abuse exposure, in another (Covey et al., 2012) consistently witnessing violence reduced income and net worth. While further research into these forms of maltreatment is clearly needed, the current evidence base relating to neglect, based as it is on 
both child welfare records and prospective report measures, provides emergent evidence of a likely causal association with long-term economic outcomes.

Although investigation of CPA and CSA was more common, accounting for five and six of the studies reviewed respectively, results varied. There appeared to be no consistent relationship between sexual abuse experiences and adult unemployment/income, although a number of studies identified an increased risk of welfare dependency, economic inactivity in the form of long-term sickness absence, having fewer assets, experiencing financial insecurity and reduced adult SES (Fergusson et al., 2013; Mullen et al., 1994; Pinto Pereira et al., 2016). There was a clearer relationship between physical abuse and employment/income related outcomes as well as other economic outcomes across studies (Covey et al., 2013; Mullen et al., 1994, 1996; Pinto Pereira et al., 2016; Strøm et al., 2013; Tanaka et al., 2011). Tanaka et al. (2011) suggested that the negative association between CSA and economic outcomes previously found in the literature could be the result of not controlling for the effect of CPA. As such, it is the interaction of CSA with other forms of maltreatment and family risk factors which produce negative outcomes rather than CSA per se, an interpretation supported by Strøm (2013) who found CSA was only related to employment in combination with CPA. Likewise, in Fergusson's (2013) study, CSA had limited association in regression models adjusted for a broad range of childhood adversities, including physical discipline/maltreatment.

Nonetheless, in one of the most extensive analyses to date, one including the widest range of maltreatment types, outcomes and family background variables, Pinto Pineiro et al. (2016) identified sexual abuse as having a more pervasive impact on economic outcomes than physical abuse, both individually and after controlling for exposure to other abuse types. This variation may be explained by a number of factors. Pinto Pineiro et al. (2016) was the only study to focus on parental sexual abuse, a form of CSA involving only a minority of victims (ONS, 2016), and one which is arguably the most damaging given the relationship between 
perpetrator and victim. Similarly, Strøm et al. (2013) noted that the weak association of CSA with work participation may reflect greater inclusion of less severe assaults within broad CSA definitions, a view supported by other review studies which highlighted how more severe CSA increased the risk of welfare receipt (Fergusson et al., 2013) and lower adult SES (Mullen et al., 1994).

In addition to differing abuse definitions, interaction between the type and timing of the economic measure used and participant gender may have contributed to varying results. The three studies which found a limited association with CSA focused primarily on employment and/or income in relation to young adults aged 20-30 years (Fergusson et al., 201308; Strøm et al., 2013; Tanaka et al., 2011), while Pinto Pereira et al. (2016) used a wider range of outcomes measured when participants were aged 50 years. There are significant differences between men and women in terms of employment over the life course, and the interrupted nature of women's participation in paid work mean that, at different times in adulthood, they may be dependent upon the incomes of others in their family (Baxter \& Taylor, 2014). As such measures of employment status and/or personal incomes, either together or alone, may not be fully indicative of women's socio-economic circumstances.

Although Pinto Pereira et al. (2016) found limited evidence of an interaction between maltreatment, gender and outcomes, other review findings suggest this plays a role. Tanaka et al. (2011) found that physical abuse reduced employment for males and noted a trend toward lower likelihood of employment among females exposed to CSA compared with males. Similarly, Fergusson et al. (2013) found that, together with family and social factors, participant gender reduced the effect of CSA on adult income to non-significant levels. Currie and Widom's (2010) research, while not able to differentiate between sexual and physical abuse, also pointed to maltreated women experiencing more enduring economic effects than men when compared to non-maltreated adults of the same gender. 
RUNNING HEAD - Child Maltreatment and Adult Poverty

While interaction between gender, maltreatment definition and type and timing of both maltreatment and outcome measures likely explains much of the difference in findings across studies, it is important to highlight that all of the studies examining CSA and/or CPA showed some association between at least one maltreatment type and at least one economic measure. Importantly, they all controlled for family of origin SES and, overall, pointed to a relatively consistent relationship between physical abuse and income/employment and were suggestive of an association of sexual abuse with outcomes such as welfare receipt, homeownership and general levels of financial insecurity. Nonetheless, the relative contribution of sexual and physical abuse to different economic outcomes for men and women requires further elucidation.

\section{CONCLUSION}

This review has highlighted that investigation into the links between child maltreatment and economic outcomes is still fairly limited. From the available evidence, it is relatively clear that 'child maltreatment', as an aggregate measure, is causally linked with economic outcomes such as income, employment, level of job skill and accumulation of assets. However, studies based on welfare records represent outcomes for only a minority of children who experience abuse. The evidence base relating to neglect is extremely limited, despite being the most common type of maltreatment. Although available studies provide emergent evidence of a likely causal association with long-term economic outcomes, the dearth of research in this area is a serious gap. Studies examining sexual abuse found less of an association with income and employment, although they did find a relationship with other outcomes such as sickness absence, assets, welfare receipt and financial insecurity, while physical abuse was more consistently associated with employment and income outcomes. 
Nonetheless, all twelve of the studies included in this review showed some association between at least one maltreatment type and at least one economic measure, with the majority controlling for family of origin SES. As such, the task for future research is less about establishing an association between maltreatment and economic outcomes and more about clarifying the relationship between specific maltreatment types and specific economic outcomes, taking account of how this may be influenced by gender and life course stage.

\section{REFERENCES}

Bagley, C., \& Mallick, K. (2000). Prediction of sexual, emotional, and physical maltreatment and mental health outcomes in a longitudinal cohort of 290 adolescent women. Child Maltreatment, 5(3), 218-226.

Barrett, A., Kamiya, Y., \& O’Sullivan, V. (2014). Childhood sexual abuse and later-life economic consequences. Journal of Behavioral and Experimental Economics, 53, 1016.

Baxter, J., \& Taylor, M. (2014). Socio-economic status of women across the life course in NSW. Women NSW.

Bywaters, P., Brady, G., Sparks, T., \& Bos, E. (2014). Child welfare inequalities: New evidence, further questions. Child \& Family Social Work, 21(3), 369-380.

Cancian, M., Yang, M.-Y., \& Slack, K. S. (2013). The effect of additional child support income on the risk of child maltreatment. Social Service Review, 87(3), 417-437.

Cawson, P., Wattam, C., Brooker, S., \& Kelly, G. (2000). Child maltreatment in the United Kingdom: a study of the prevalence of abuse and neglect. London: NSPCC.

Covey, H. C., Menard, S., \& Franzese, R. J. (2013). Effects of adolescent physical abuse, exposure to neighborhood violence, and witnessing parental violence on adult socioeconomic status. Child Maltreatment, 18(2), 85-97.

Currie, J., \& Widom, C. S. (2010). Long-term consequences of child abuse and neglect on adult economic well-being. Child Maltreatment, 15(2), 111-120. 
RUNNING HEAD - Child Maltreatment and Adult Poverty

Elamin, M. B., \& Montori, V. M. (2012). The Hierarchy of Evidence: From Unsystematic Clinical Observations to Systematic Reviews BT - Neurology: An Evidence-Based Approach. In J. G. Burneo, B. M. Demaerschalk, \& M. E. Jenkins (Eds.), Neurology (pp. 11-24). New York, NY: Springer.

Fahy, A. E., Stansfeld, S. A., Smuk, M., Lain, D., van der Horst, M., Vickerstaff, S., \& Clark, C. (2017). Longitudinal associations of experiences of adversity and socioeconomic disadvantage during childhood with labour force participation and exit in later adulthood. Social Science \& Medicine, 183, 80-87.

Fein, D. J., \& Lee, W. S. (2003). The impacts of welfare reform on child maltreatment in Delaware. Children and Youth Services Review, 25(1), 83-111.

Felitti, V. J., \& Anda, R. F. (2010). The relationship of adverse childhood experiences to adult medical disease, psychiatric disorders and sexual behavior: Implications for healthcare. The Impact of Early Life Trauma on Health and Disease: The Hidden Epidemic, 77-87.

Fergusson, D.,McLeod, G. \& Horwood, J. (2013) Childhood sexual abuse and adult developmental outcomes: Findings from a 30-year longitudinal study in New Zealand. Child Abuse and Neglect. 37, 664-674

Frias-Armenta, M., \& McCloskey, L. A. (1998). Determinants of harsh parenting in Mexico. Journal of Abnormal Child Psychology, 26(2), 129-139.

Grimes, D. A., \& Schulz, K. F. (2002). Cohort studies: marching towards outcomes. The Lancet, 359(9303), 341-345.

Hadi, A. (2000). Child abuse among working children in rural Bangladesh: prevalence and determinants. Public Health, 114(5), 380-384.

Harkonmäki, K., Korkeila, K., Vahtera, J., Kivimäki, M., Suominen, S., Sillanmäki, L., \& 
RUNNING HEAD - Child Maltreatment and Adult Poverty

Koskenvuo, M. (2007). Childhood adversities as a predictor of disability retirement. Journal of Epidemiology \& Community Health, 61(6), 479-484.

Jackson, Y., Gabrielli, J., Fleming, K., Tunno, A. M., \& Makanui, P. K. (2014). Untangling the relative contribution of maltreatment severity and frequency to type of behavioral outcome in foster youth. Child Abuse \& Neglect, 38(7), 1147-1159.

Kendall-Tackett, K., \& Becker-Blease, K. (2004). The importance of retrospective findings in child maltreatment research. Child Abuse \& Neglect, 28(7), 723-727.

Krug, E. G., Mercy, J. A., Dahlberg, L. L., \& Zwi, A. B. (2002). The world report on violence and health. The Lancet, 360(9339), 1083-1088.

Lund, T., Andersen, J. H., Winding, T. N., Biering, K., \& Labriola, M. (2013). Negative life events in childhood as risk indicators of labour market participation in young adulthood: a prospective birth cohort study. PloS One, 8(9), e75860.

Moher D, Liberati A, Tetzlaff J, Altman DG, The PRISMA Group (2009) Preferred Reporting Items for Systematic Reviews and Meta-Analyses: The PRISMA Statement. PLoS Med6(7): e1000097. https://doi.org/10.1371/journal.pmed.1000097

Mersky, J. P., \& Topitzes, J. (2010). Comparing early adult outcomes of maltreated and non-maltreated children: A prospective longitudinal investigation. Children and Youth Services Review, 32(8), 1086-1096.

Mullen, P. E., Martin, J. L., Anderson, J. C., Romans, S. E., \& Herbison, G. P. (1994). The effect of child sexual abuse on social, interpersonal and sexual function in adult life. The British Journal of Psychiatry: The Journal of Mental Science, 165(1), 35-47.

Mullen, P. E., Martin, J. L., Anderson, J. C., Romans, S. E., \& Herbison, G. P. (1996). The long-term impact of the physical, emotional, and sexual abuse of children: A community study. Child Abuse \& Neglect, 20(1), 7-21. 
RUNNING HEAD - Child Maltreatment and Adult Poverty

Norman, R. E., Byambaa, M., De, R., Butchart, A., Scott, J., \& Vos, T. (2012). The long-term health consequences of child physical abuse, emotional abuse, and neglect: a systematic review and meta-analysis. PLoS Medicine, 9(11), e1001349.

ONS. (2016). Abuse during childhood: Findings from the Crime Survey for England and Wales, year ending March 2016. Newport, UK.

Petersen, A. C., Joseph, J., \& Feit, M. (Eds.). (2014). New Directions in Child Abuse and Neglect Research. Washington, DC: Institute of Medicine and National Research Council. Retrieved from https://www.nap.edu/catalog/18331/new-directions-inchild-abuse-and-neglect-research

Pinto Pereira, S. M., Li, L., \& Power, C. (2016). Child maltreatment and adult living standards at 50 years. Pediatrics, e20161595.

Ryan, R. (2013). Cochrane Consumers and Communication Review Group: data synthesis and analysis. Cochrane Consumers and Communication Review Group, 1-5.

Shook, K., \& Testa, M. (1997). Cost-savings evaluation of the Norman Program: Final report to the Department of Children and Family Services. Chicago: Illinois Department of Children and Family Services.

Stoltenborgh, M., Bakermans-Kranenburg, M. J., Alink, L. R. A., \& IJzendoorn, M. H. (2015). The prevalence of child maltreatment across the globe: Review of a series of meta-analyses. Child Abuse Review, 24(1), 37-50.

Strøm, I. F., Thoresen, S., Wentzel-Larsen, T., \& Dyb, G. (2013). Violence, bullying and academic achievement: A study of 15-year-old adolescents and their school environment. Child Abuse \& Neglect, 37(4), 243-251.

Tanaka, M., Jamieson, E., Georgiades, K., Duku, E. K., Boyle, M. H., \& MacMillan, H. L. (2011). The association between childhood abuse and labor force outcomes in young adults: Results from the Ontario child health study. Journal of Aggression, Maltreatment \& Trauma, 20(8), 821-844. 
Teicher, M. H., Samson, J. A., Anderson, C. M., \& Ohashi, K. (2016). The effects of childhood maltreatment on brain structure, function and connectivity. Nature Reviews Neuroscience, 17(10), 652-666.

UK Data Service. (1958). National Child Development Study (NCDS). Colcheste, UK. Vinnerljung, B., Sundell, K., Löfholm, C. A., \& Humlesjö, E. (2006).

Former Stockholm

child protection cases as young adults: Do outcomes differ between those that received services and those that did not? Children and Youth Services Review, 28(1), 5977.

Wolff, J., Lamb, E., \& Zur-Szpiro, E. (2015). A philosophical review of poverty. York:

Joseph Rowntree Foundation.

Zielinski, D. S. (2009). Child maltreatment and adult socioeconomic well-being. Child Abuse

\& Neglect, 33(10), 666-678. 
Table 1- Key Findings from Studies Reporting on Generic/Aggregate Child Maltreatment Measures

\begin{tabular}{|c|c|c|}
\hline $\begin{array}{l}\text { Maltreatment Measure(s) } \\
\text { and age when measured }\end{array}$ & $\begin{array}{l}\text { Outcome(s) and age when } \\
\text { measured }\end{array}$ & Key Findings \\
\hline \multicolumn{3}{|l|}{ Currie \& Widom (2010) } \\
\hline $\begin{array}{l}\text { Court substantiated cases of } \\
\text { CPA, CSA and neglect ( } 0 \text { - } \\
11 \mathrm{yrs})\end{array}$ & $\begin{array}{l}\text { - Having a skilled job } \\
\text { - Employment status } \\
\text { - Annual earnings } \\
\text { - Assets (bank account, stock, } \\
\text { vehicle, home) } \\
\text { - Non-mortgage debt (41yrs) }\end{array}$ & $\begin{array}{l}\text { After controlling for age, race/ethnicity, sex and family characteristics, combined CPA, CSA } \\
\text { and neglect was related to: } \\
\text { - Lower annual earnings }[\beta=-\$ 6,552, \mathrm{SE}=\$ 2,844 * *] \\
\text { - Reduced employment }\left[\mathrm{OR}=.46(95 \% \mathrm{CI} .26-.80)^{* *}\right] \\
- \text { Lower level of job skill }[\mathrm{OR}=.52(95 \% \mathrm{CI} .32-.84 * *)] \\
- \text { Less likely to own a bank account }[\mathrm{OR}=.83(95 \% \mathrm{CI} .50-1.37)] \\
- \text { Less likely to own stock }\left[\mathrm{OR}=.58\left(95 \% \mathrm{CI} .28-1.01^{*}\right)\right]\end{array}$ \\
\hline
\end{tabular}


- Less likely to own a vehicle [OR = .58 (95\% CI .34-.99*)

- Lower likelihood of owning a home $[\mathrm{OR}=.72(95 \% \mathrm{CI} .44-1.17)]$

- Higher likelihood of having non-mortgage debt $[\mathrm{OR}=1.56$ (95\% CI .95-2.55)]

- Women's economic outcomes were more strongly affected by the experience of childhood maltreatment than men's. 


\begin{tabular}{|c|c|c|}
\hline $\begin{array}{l}\text { Self-reported abuse } \\
\text { (combined parental CPA and } \\
\text { CSA) }[45 \mathrm{yrs}]\end{array}$ & $\begin{array}{l}\text { - Current labor participation, } \\
\text { including employment, } \\
\text { permanent sickness/disability, } \\
\text { retirement, homemaker or other } \\
\text { (55yrs) }\end{array}$ & $\begin{array}{l}\text { After controlling for gender, childhood mental health, educational disengagement and } \\
\text { adulthood factors (no control for family of origin SES): } \\
\text { - Abuse was related to increased risk of being absent from work due to permanent sickness } \\
\text { or disability }[\mathrm{OR}=1.52(95 \% \text { CI } 1.04-2.23)]^{\mathrm{b}}\end{array}$ \\
\hline \multicolumn{3}{|c|}{ Harkonmäki, Korkeila, Vahtera, Kivimäki, Suominen, Sillanmäki and Koskenvuo (2007) } \\
\hline $\begin{array}{l}\text { Self-reported exposure to } \\
\text { childhood adversities } \\
\text { including family conflict and } \\
\text { frequent fear of a family } \\
\text { member (40-54yrs) }\end{array}$ & $\begin{array}{l}\text { - Disability retirement (45- } \\
\text { 59yrs) }\end{array}$ & $\begin{array}{l}\text { After controlling for adult risk factors (no control for family of origin SES): } \\
\text { - Frequent fear of a family member increased risk of disability retirement }[\mathrm{OR}=1.94(95 \% \\
\text { CI } 1.45-2.59)]^{\text {b }}\end{array}$ \\
\hline \multicolumn{3}{|c|}{ Lund, Andersen,Winding, Biering and Labriola (2013) } \\
\hline $\begin{array}{l}\text { Self-reported exposure to } \\
\text { negative life events (NLE) } \\
\text { including being abused by } \\
\text { someone known to the } \\
\text { subject (14-15yrs) }\end{array}$ & $\begin{array}{l}\text { - Labor market participation (21- } \\
22 \mathrm{yrs})\end{array}$ & $\begin{array}{l}\text { After controlling for childhood SES, being abused: } \\
\text { - Increased the risk of lower labour force participation males }[\mathrm{OR}=2.74(95 \% 1.33-5.63)]^{\mathrm{b}} \\
\text { and females }[\mathrm{OR}=4.92(95 \% \mathrm{CI} 2.79-8.65)]^{\mathrm{b}} \\
\text { - The effect for females remained significant after controlling for school grades, } \\
\text { educational plans, vocational expectations }[\mathrm{OR}=5.40(95 \% \mathrm{CI} 2.78-1.49)] \text { as well as }\end{array}$ \\
\hline
\end{tabular}




\begin{tabular}{|c|c|c|}
\hline & & $\begin{array}{l}\text { health }[\mathrm{OR}=5.10(95 \% \text { CI } 2.60-9.97)]^{\mathrm{b}} \\
\text { - The effect for males became non-significant for males after controlling for school } \\
\text { grades, educational plans, vocational expectations }[\mathrm{OR}=1.72(95 \% \text { CI } 0.68-4.33)]^{\mathrm{b}}\end{array}$ \\
\hline \multicolumn{3}{|l|}{ Mersky and Topzites (2010) } \\
\hline $\begin{array}{l}\text { Court records and referrals } \\
\text { to child protection services } \\
\text { indicative of maltreatment } \\
(0-17 \mathrm{yrs})\end{array}$ & $\begin{array}{l}\text { - Regular employment/college } \\
\text { attendance } \\
\text { - Above average income over } \\
\text { 2yrs (18-24yrs) }\end{array}$ & $\begin{array}{l}\text { After controlling for a range of parental social factors, maltreatment was related to: } \\
\text { - A } 34 \% \text { reduction in income }\left(\beta=-.342^{* *}\right) \\
\text { - A } 23 \% \text { reduction in employment or college attendance }\left(\beta=-.303^{* *}\right)\end{array}$ \\
\hline \multicolumn{3}{|c|}{ Vinnerljung, Sundell, Lofholm and Humlesjo (2006) } \\
\hline $\begin{array}{l}\text { Children born } 1968 / 1975 \\
\text { known to child protection } \\
\text { services (0-18yrs) }\end{array}$ & $\begin{array}{l}\text { - Welfare receipt during year } \\
\text { (25yrs) }\end{array}$ & $\begin{array}{l}\text { - In regression analysis comparing those children referred to child protection services who } \\
\text { received a service with that those did not (no control for family of origin SES), } \\
\text { receiving a a service was related to an increase in welfare receipt }\left(\beta=.35^{* * *}\right)\end{array}$ \\
\hline
\end{tabular}

Notes: $\mathrm{CPA}=$ child physical abuse $; \mathrm{CSA}=$ child sexual abuse; $\mathrm{CEA}=$ child emotional abuse; $\mathrm{CI}=$ confidence interval; $\mathrm{SE}=$ standard error; $\beta=$ beta coefficient; $b=$ unstandardized co-efficient; ${ }^{b}$ level of significance not reported; ${ }^{*} \mathrm{p} \leq .05 ; * * \mathrm{p} \leq .01 ; * * * \mathrm{p} \leq .001$ 
Table 2- Key Findings from Studies Reporting on Specific and Comparative Child Maltreatment Measures

\begin{tabular}{|c|c|c|}
\hline $\begin{array}{l}\text { Maltreatment } \\
\text { Measure(s) and } \\
\text { age when } \\
\text { measured }\end{array}$ & $\begin{array}{l}\text { Outcome (s) and } \\
\text { age when } \\
\text { measured }\end{array}$ & Key Findings \\
\hline \multicolumn{3}{|c|}{ Covey, Menard and Franzese (2013) } \\
\hline $\begin{array}{l}\text { Self-reported past } \\
\text { year CPA (aged } \\
11-17 / 15-21 \mathrm{yrs}) \\
\text { Ever witnessing } \\
\text { parental violence } \\
\text { as a child (24- } \\
30 / 37-43 \mathrm{yrs})\end{array}$ & $\begin{array}{l}\text { Net worth } \\
\text { Employment } \\
\text { status } \\
\text { Past year personal } \\
\text { income (36-43yrs) }\end{array}$ & $\begin{array}{l}\text { After controlling for family social factors and exposure to other abuse types: } \\
\text { - CPA was related to reduced income }\left[\mathrm{b}=-.608, \mathrm{SE}=.193^{* *}\right] \text { and net worth }\left[\mathrm{b}=-.661, \mathrm{SE}=.195^{* * *}\right] \text { but not employment } \\
{[\mathrm{b}=-.257, \mathrm{SE}=.356]} \\
\text { - Consistently witnessing violence reduced income }\left[\mathrm{b}=-.312, \mathrm{SE}=.159^{*}\right] \text { and net worth }\left[\mathrm{b}=-.401, \mathrm{SE}=.163^{*}\right] \text { but not } \\
\text { employment }[\mathrm{b}=.518, \mathrm{SE}=.308] \text {, } \\
\text { - Inconsistently witnessing violence was not related to employment }[\mathrm{b}=-.221, \mathrm{SE}=.355] \text { income }[\mathrm{b}=-.061, \mathrm{SE}=.168] \text { or } \\
\text { net worth }[\mathrm{b}=-.177, \mathrm{SE}=.171]\end{array}$ \\
\hline \multicolumn{3}{|c|}{ Currie \& Widom (2010) } \\
\hline $\begin{array}{l}\text { Court } \\
\text { substantiated cases }\end{array}$ & $\begin{array}{l}\text { Having a skilled } \\
\text { job }\end{array}$ & In the matched sample after controlling for age, race/ethnicity, sex and family characteristics, neglect was related to: \\
\hline
\end{tabular}




\begin{tabular}{|c|c|c|}
\hline $\begin{array}{l}\text { of neglect }(0- \\
11 \mathrm{yrs})\end{array}$ & $\begin{array}{l}\text { Employment } \\
\text { status } \\
\text { Annual earnings } \\
\text { Assets (bank } \\
\text { account, stock, } \\
\text { vehicle, home) } \\
\text { Non-mortgage } \\
\text { debt (41yrs) }\end{array}$ & $\begin{array}{l}\text { Lower level of job skill }[\mathrm{OR}=.64(95 \% \mathrm{CI} .45-.91 *)] \text {, reduced employment }\left[\mathrm{OR}=.59\left(95 \% \mathrm{CI} .40-.86^{* *}\right)\right] \text {, lower annual } \\
\text { earnings }[\beta=-\$ 7,005, \mathrm{SE}=\$ 1,805 * * *] \text {, and fewer assets (bank account }[\mathrm{OR}=.74(95 \% \mathrm{CI} .52-1.05)] \text {, stock }[\mathrm{OR}=.56 \\
\left.\left(95 \% \mathrm{CI} .35-.88^{*}\right)\right] \text {, ownership of a vehicle }[\mathrm{OR}=.62(95 \% \mathrm{CI} .42-.92 *)] \text { or home ownership }[\mathrm{OR}=.55(95 \% \mathrm{CI} .39- \\
79 * * *)],) \text { and higher likelihood of having non-mortgage debt }[\mathrm{OR}=.81(95 \% \mathrm{CI} .57-1.15)],)\end{array}$ \\
\hline
\end{tabular}

\section{Fahy, Stansfeld, Smuk, Lain, van der Horst, Vickerstaff and Clark (2017)}

\begin{tabular}{|c|c|c|}
\hline $\begin{array}{l}\text { Prospective } \\
\text { neglect based on } \\
\text { reports that child } \\
\text { appeared "scruffy } \\
\text { or underfed" ( } 7 \& \\
11 \text { yrs) }\end{array}$ & $\begin{array}{l}\text { Labor } \\
\text { participation } \\
\text { (including } \\
\text { permanent } \\
\text { sickness or } \\
\text { disability) (55yrs) }\end{array}$ & $\begin{array}{l}\text { - After adjusting for gender, childhood mental health, educational engagement and adult factors (no control for family } \\
\text { SES), neglect was related to increased risk of being absent from work due permanent sickness or disability [OR=1.93 } \\
(95 \% \text { CI } 1.22-3.05)]^{b}\end{array}$ \\
\hline $\mathbf{F}$ & $\operatorname{od}($ & 013) \\
\hline
\end{tabular}




\begin{tabular}{|c|c|c|}
\hline $\begin{array}{l}\text { reported CSA } \\
\text { prior to age } 16(18 \\
-21 \mathrm{yrs})\end{array}$ & $\begin{array}{l}\text { personal income } \\
(30 \mathrm{yrs}) \\
\text { Receipt of a } \\
\text { government social } \\
\text { welfare (25-30yrs) }\end{array}$ & $\begin{array}{l}\left.1.114^{* * *}\right) \text { and increased welfare dependence }\left(\beta=0.452, \mathrm{SE}=0.084^{* * *}\right) \\
. \text { After controlling for a range of family functioning, social and child factors, welfare receipt remained significant }(\beta= \\
\left..310, \mathrm{SE}=.099^{* *} \text {, effect size }=.30\right) \text { but income was } \operatorname{not}(\beta=-.730, \mathrm{SE}=1.102)\end{array}$ \\
\hline \multicolumn{3}{|c|}{ Mullen, Martin, Anderson and Romans (1994); Mullen, Martin, Anderson, Romans and Herbison (1996) } \\
\hline $\begin{array}{l}\text { Retrospective self- } \\
\text { reported CSA, } \\
\text { CPA and CEA } \\
\text { before age } 16\end{array}$ & $\begin{array}{l}\text { Women's SES } \\
\text { (aged } 16-64 \mathrm{yrs} \text { ), } \\
\text { based on current } \\
\text { occupation and, } \\
\text { where relevant, } \\
\text { that of the partner. }\end{array}$ & $\begin{array}{l}\text { Mullen et al. (1994) - analysis focused on CSA as the main predictor in regression models } \\
\text { - In unadjusted models, CSA [OR }=2.24(95 \% \text { CI } 1.29-3.90]^{\mathrm{b}} \text { group were likely to have a decline in SES } \\
\text { - CPA }[\mathrm{OR}=2.47(95 \% \text { CI } 1.10-5.55)]^{\mathrm{b},} \text { maternal CEA }[\mathrm{OR}=2.13(95 \% \text { CI } 1.25-3.60)]^{\mathrm{b}} \text { and paternal CEA }[\mathrm{OR}=2.13 \\
(95 \% \text { CI } 1.25-3.60)]^{\mathrm{b}} \text { were related to decline in SES } \\
\text { - After controlling for family/social and other risk factors including CPA, CEA and CSA remained associated with SES } \\
\text { decline }[\mathrm{OR}=1.34(95 \% \text { CI } 1.01-1.78)]^{\mathrm{b}} \\
\text { Mullen et al. }(1996)-\text { analysis focused on CSA, CPA and CEA in separate regression models } \\
\text { - In unadjusted models, CSA }[\mathrm{OR}=2.46(95 \% \text { CI } 1.28-4.73)]^{\mathrm{b}} \text { and CPA }[\mathrm{OR}=2.33(95 \% \mathrm{CI} 1.08-4.99)]^{\mathrm{b}} \text { were }\end{array}$ \\
\hline
\end{tabular}




\begin{tabular}{|c|c|c|}
\hline & & $\begin{array}{l}\text { associated, and CEA was not (results not reported) } \\
\text { - After controlling for family/social factors, CSA and CPA were no longer related (results not reported) }\end{array}$ \\
\hline \multicolumn{3}{|c|}{ Pinto Pereira, Li and Power (2017) } \\
\hline $\begin{array}{l}\text { Prospective } \\
\text { neglect measure } \\
\text { based on parent } \\
\text { and teacher report } \\
\text { (7-11yrs). } \\
\text { Retrospective self- } \\
\text { reported emotional } \\
\text { neglect, sexual, } \\
\text { physical and } \\
\text { psychological } \\
\text { abuse and } \\
\text { witnessing } \\
\text { domestic violence }\end{array}$ & $\begin{array}{l}\text { Long-term } \\
\text { sickness absence } \\
\text { [LTS] ( } 23 \text { \& } \\
\text { 50yrs) } \\
\text { not in } \\
\text { employment, } \\
\text { education, or } \\
\text { training } \\
\text { [NEET](23 \& } \\
\text { 50yrs) } \\
\text { lack of assets } \\
\text { (50yrs) } \\
\text { receipt of income- }\end{array}$ & 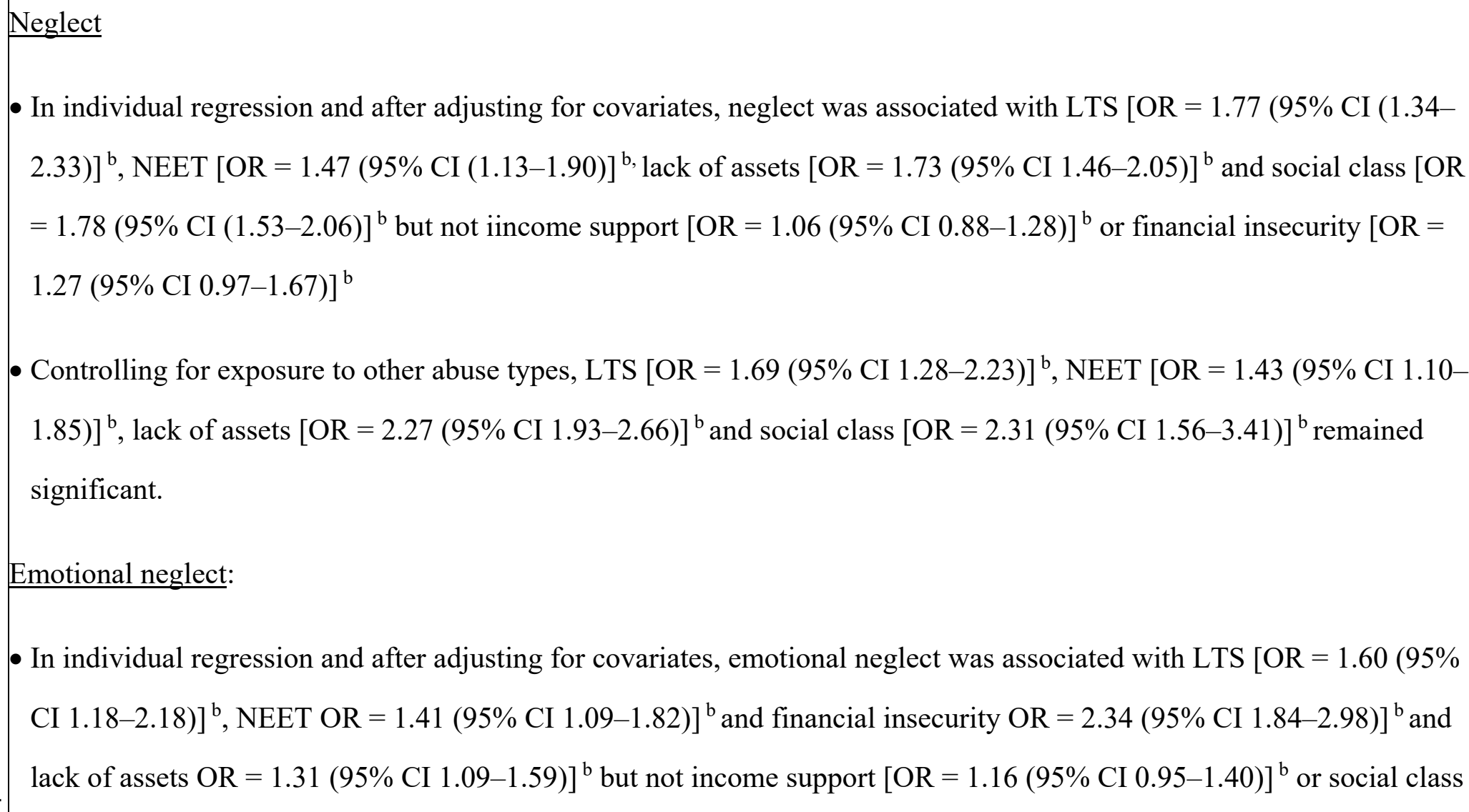 \\
\hline
\end{tabular}




\begin{tabular}{|c|c|c|}
\hline (45yrs). & $\begin{array}{l}\text { related support } \\
(45 \mathrm{yrs}) \\
\text { social class }(23 \& \\
50 \mathrm{yrs})\end{array}$ & 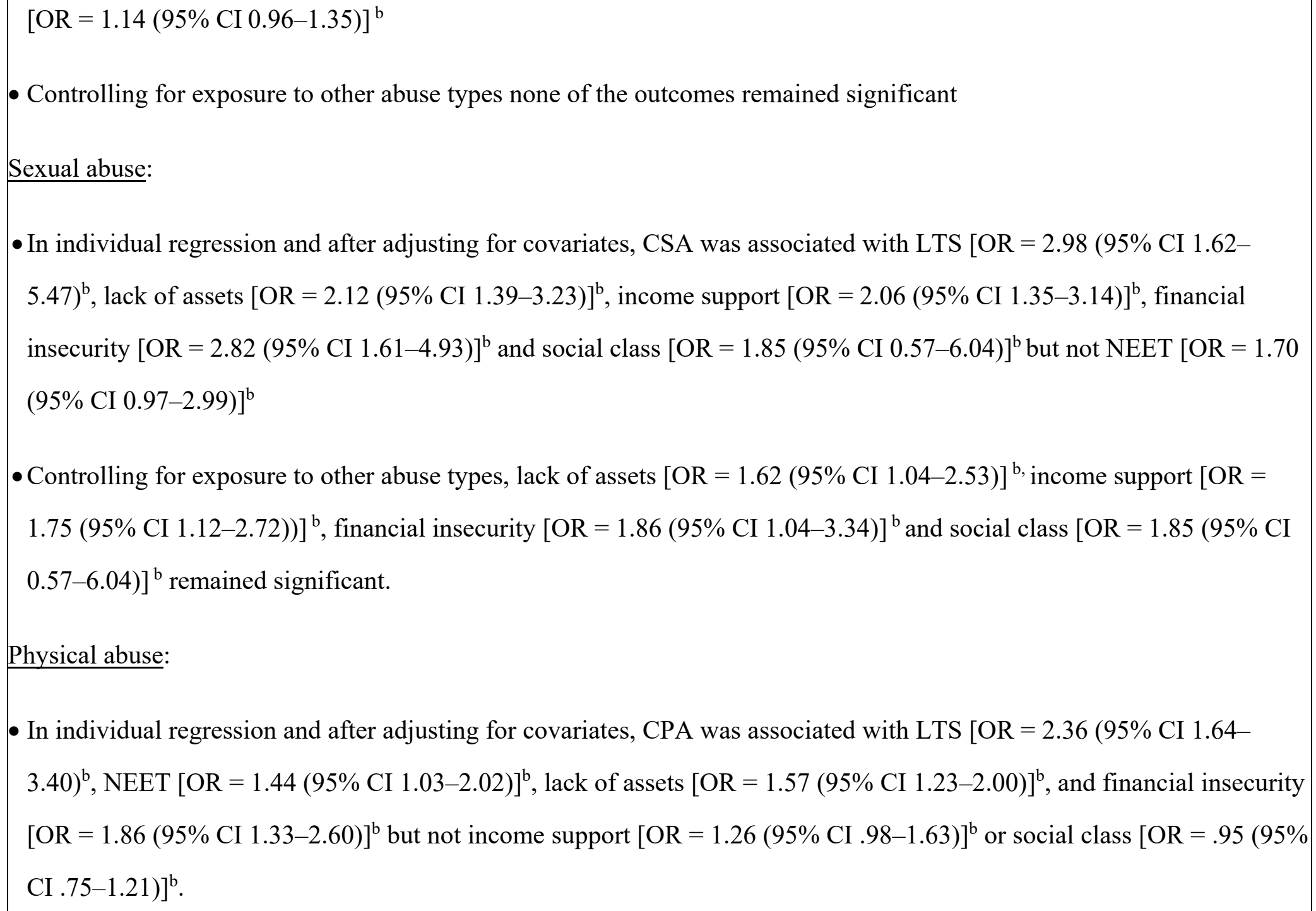 \\
\hline
\end{tabular}




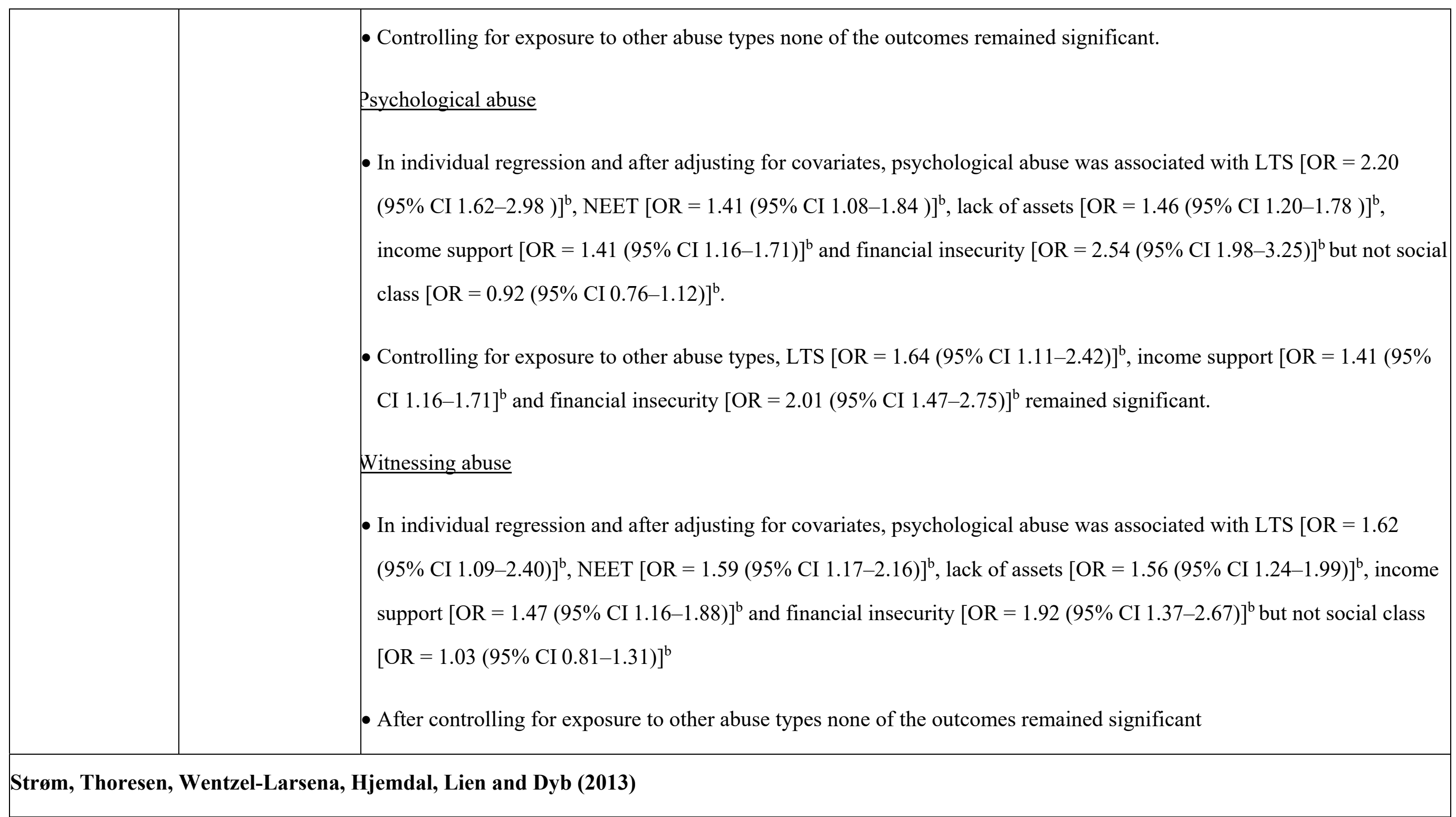




\begin{tabular}{|c|c|c|}
\hline $\begin{array}{l}\text { Retrospective } \\
\text { self-reported } \\
\text { experiences of } \\
\text { CSA, CPA and } \\
\text { bullying in past } \\
\text { year (15-16yrs) }\end{array}$ & $\begin{array}{l}\text { - Past year work } \\
\text { participation (21- } \\
24 y r s)\end{array}$ & 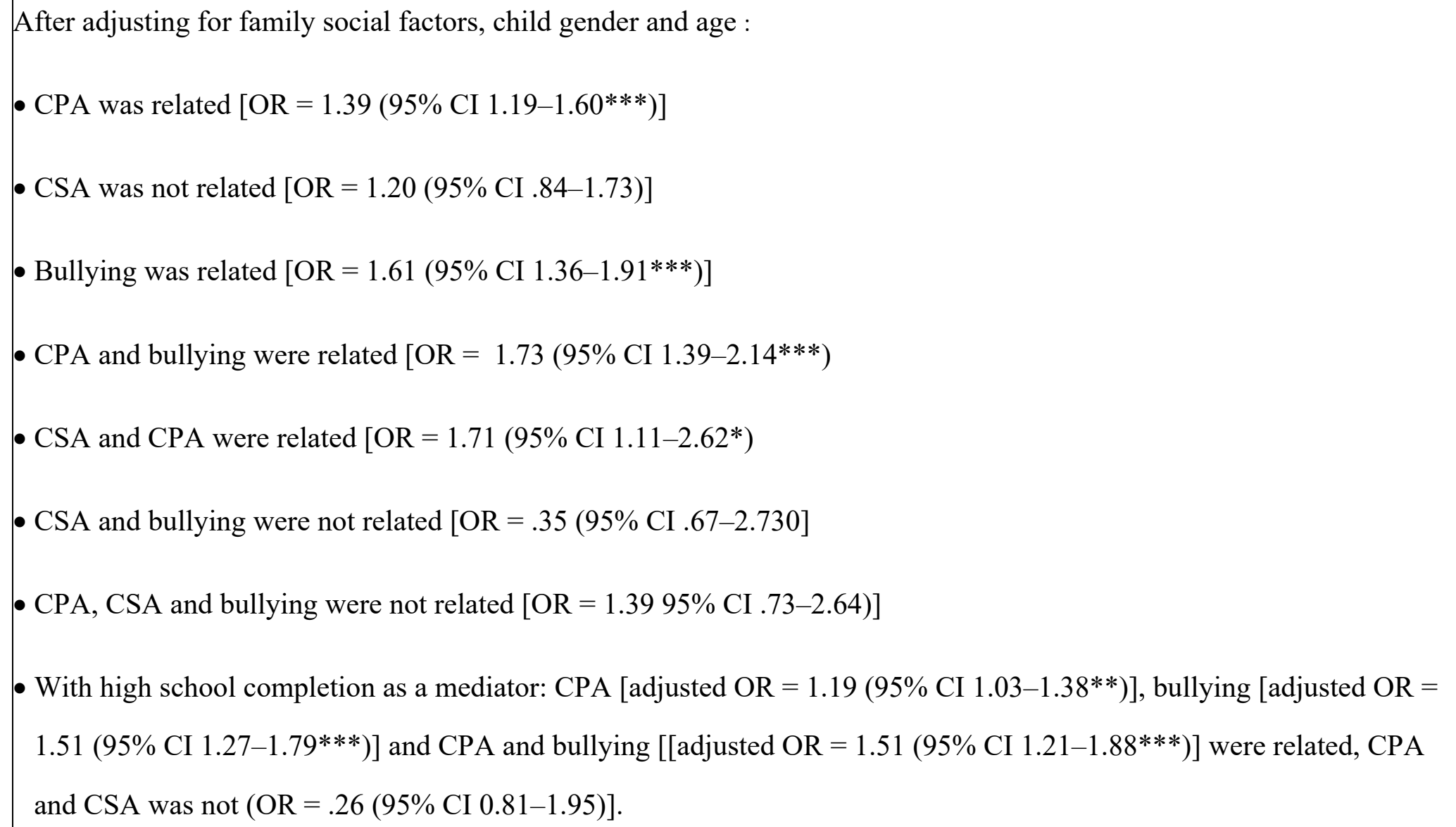 \\
\hline \multicolumn{3}{|c|}{ Tanaka, Jamieson, Duku, Boyle and MacMillan (2011) } \\
\hline $\begin{array}{l}\text { Retrospective } \\
\text { self-reported }\end{array}$ & $\begin{array}{l}\text { - Employed in past } \\
12 \text { months }\end{array}$ & $\begin{array}{l}\text { After controlling for family social factors, child and adult factors and exposure to other abuse types: } \\
\text { - Severe CPA was related to unemployment for males but not females }\left[\mathrm{OR}=2.5\left(95 \% \mathrm{CI} 1.2,5.3^{* *}\right)\right] \text { and reduced income }\end{array}$ \\
\hline
\end{tabular}




\begin{tabular}{|c|c|c|}
\hline $\begin{array}{l}\text { CSA, severe } \\
\text { CPA and non- } \\
\text { severe CPA } \\
\text { before the age of } \\
16\end{array}$ & $\begin{array}{l}\text { Annual personal } \\
\text { income aged ( } 21- \\
25 \mathrm{yrs})\end{array}$ & $\begin{array}{l}\text { for both genders }\left[\beta=-.325, \mathrm{SE}=.116^{*}\right] \\
\text { The relationship between male unemployment and severe CPA was partially mediated by education, physical and mental } \\
\text { health }[\mathrm{OR}=0.55(95 \% \mathrm{CI} 0.31-0.97)]^{*} \text {, as was income }\left[\beta=-.296, \mathrm{SE}=.112^{*}\right] \\
\text { - Non-severe CPA was not related to employment }[\mathrm{OR}=1.64(95 \% \mathrm{CI} .99-2.70)] \text { or income }[\beta=-.084, \mathrm{SE}=.113] \text {. } \\
\text { - CSA was not related to employment }[\mathrm{OR}=.74(95 \% \mathrm{CI} .51-1.08)] \text { or income }[\beta=-.009, \mathrm{SE}=.111] \text {. }\end{array}$ \\
\hline
\end{tabular}

Notes: $\mathrm{CPA}=$ child physical abuse $\mathrm{CSA}=$ child sexual abuse $\mathrm{CEA}=$ child emotional abuse $\mathrm{CI}=$ confidence interval; $\mathrm{SE}=$ standard error; $\beta=$ beta coefficient; $\mathrm{b}$ $=$ unstandardized co-efficient; ${ }^{\mathrm{b}}$ level of significance not reported; ${ }^{*} \mathrm{p} \leq .05 ; * * \mathrm{p} \leq .01 ; * * * \mathrm{p} \leq .001$ 



\section{Supplemental Information}

\section{Supplemental Table 1 - Search Terms by Database}

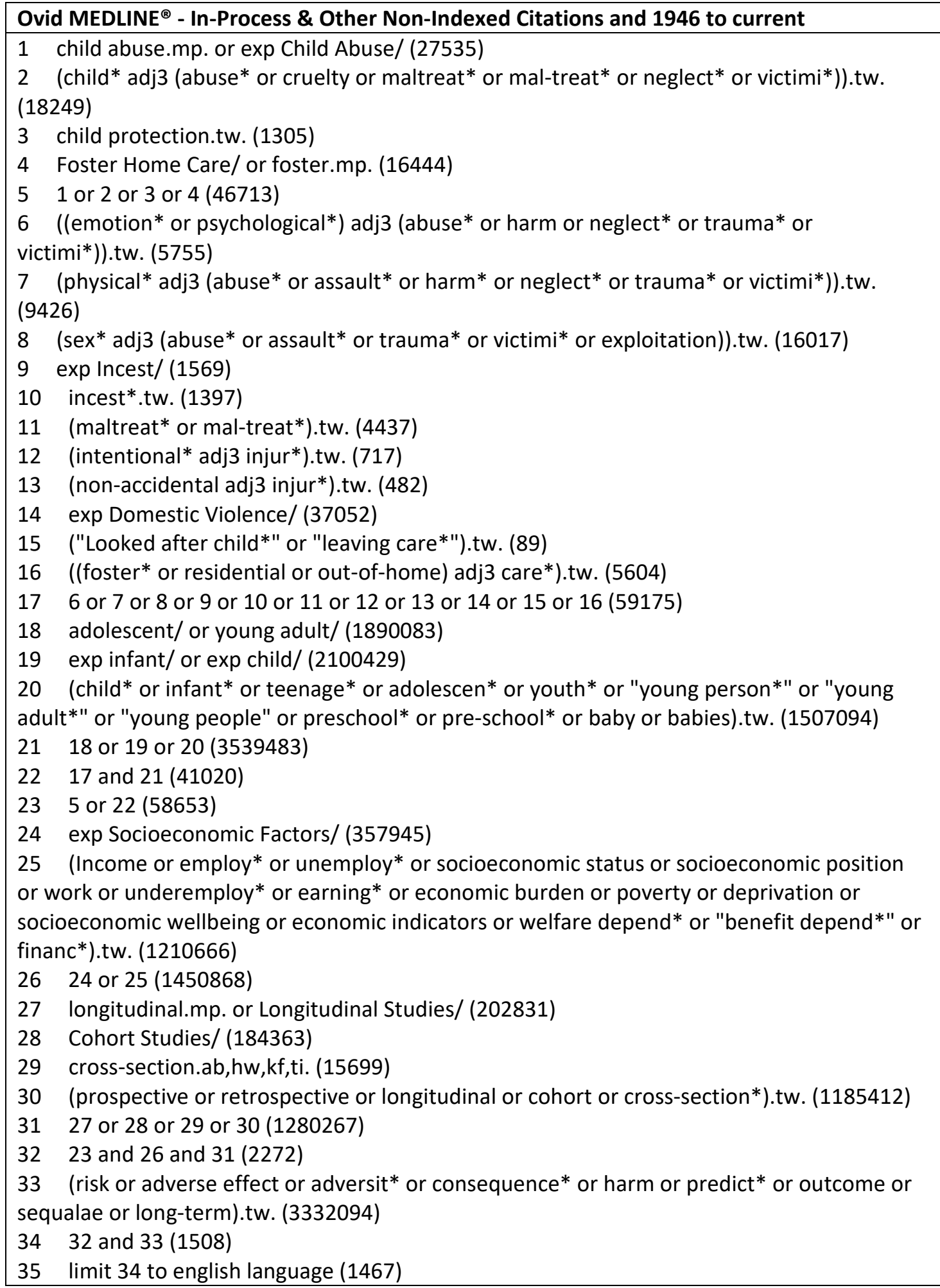




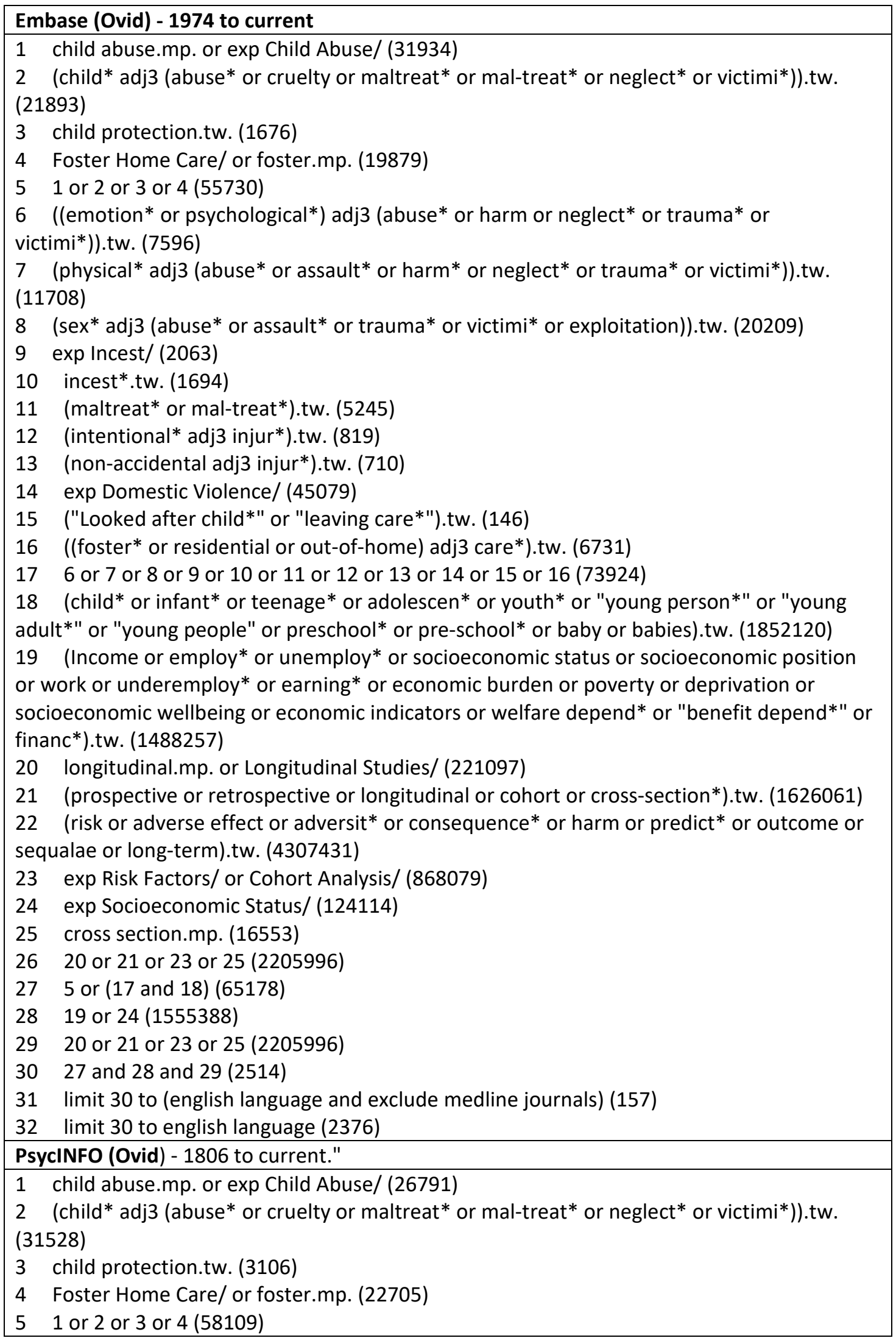




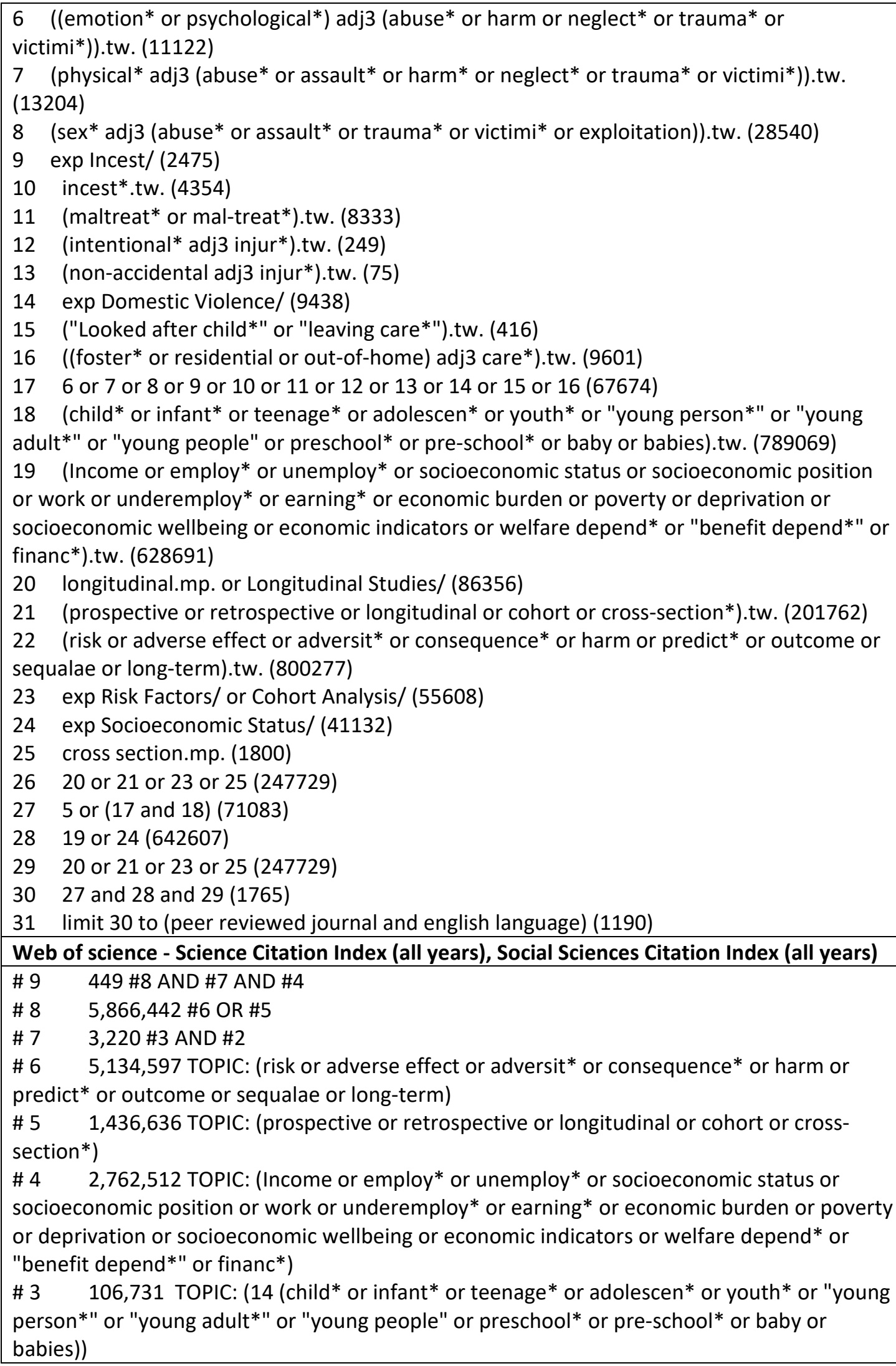




\begin{tabular}{|c|c|}
\hline $\begin{array}{l}\# 2 \\
\text { negle } \\
\text { Dome } \\
\text { psych } \\
\text { (phys } \\
\text { TOPIC } \\
\text { (inces } \\
\text { TOPIC } \\
\text { NEAR }\end{array}$ & $\begin{array}{l}\text { 85,975 TOPIC: (child* NEAR/3 (abuse* or cruelty or maltreat* or mal-treat* or } \\
\text { ct* or victimi*)) OR TOPIC: (child protection or "Foster Home Care" or "foster care" or } \\
\text { stic Violence or "Looked after child*" or "leaving care*") OR TOPIC: ((emotion* or } \\
\text { ological*) NEAR/3 (abuse* or harm or neglect* or trauma* or victimi*)) OR TOPIC: } \\
\text { cal* NEAR/3 (abuse* or assault* or harm* or neglect* or trauma* or victimi*)) OR } \\
\text { ( (sex* NEAR/3 (abuse* or assault* or trauma* or victimi* or exploitation)) OR TOPIC: } \\
\text { t) OR TOPIC: ((maltreat* or mal-treat*)) OR TOPIC: ((intentional* NEAR/3 injur*)) OR } \\
\text { ((non-accidental NEAR/3 injur*)) OR TOPIC: ((foster* or residential or out-of-home) } \\
3 \text { care*) }\end{array}$ \\
\hline Econl & t (EBSCOhost) - All years \\
\hline S21 & $\mathrm{S} 17$ or $\mathrm{S} 18$ or $\mathrm{S} 19$ \\
\hline S20 & S18 OR S19 \\
\hline S19 & S10 AND S11 AND S12 AND S13 \\
\hline S18 & S11 AND S12 AND S15 \\
\hline S17 & S11 AND S15 AND S16 \\
\hline S16 & S12 OR S13 \\
\hline S15 & S10 AND S14 \\
\hline & $\begin{array}{l}\text { child* or infant* or teenage* or adolescen* or youth* or "young person*" or "young } \\
\text { " or "young people" or preschool* or pre-school* or baby or babies }\end{array}$ \\
\hline $\begin{array}{l}\text { S13 } \\
\text { or sec }\end{array}$ & $\begin{array}{l}\text { risk or adverse effect or adversit* or consequence* or harm or predict* or outcome } \\
\text { ualae or long-term }\end{array}$ \\
\hline S12 & prospective or retrospective or longitudinal or cohort or cross-section* \\
\hline $\begin{array}{l}\text { S11 } \\
\text { or wo } \\
\text { socio } \\
\text { finane }\end{array}$ & $\begin{array}{l}\text { Income or employ* or unemploy* or socioeconomic status or socioeconomic position } \\
\text { rk or underemploy* or earning* or economic burden or poverty or deprivation or } \\
\text { economic wellbeing or economic indicators or welfare depend* or "benefit depend*" or } \\
\text { * }\end{array}$ \\
\hline S10 & S1 OR S2 OR S3 OR S4 OR S5 OR S6 OR S7 OR S8 OR S9 \\
\hline $\begin{array}{l}\text { S9 } \\
\text { reside }\end{array}$ & $\begin{array}{l}\text { intentional* NEAR/3 injur* OR non-accidental NEAR/3 injur* OR ( foster* or } \\
\text { ntial or out-of-home) NEAR/3 care*) }\end{array}$ \\
\hline S8 & incest* or maltreat* or mal-treat* \\
\hline & sex* NEAR/3 (abuse* or assault* or trauma* or victimi* or exploitation \\
\hline & physical* NEAR/3 (abuse* or assault* or harm* or neglect* or trauma* or victimi* \\
\hline $\begin{array}{l}\text { S5 } \\
\text { victim }\end{array}$ & $\begin{array}{l}\text { emotion* or psychological*) NEAR/3 (abuse* or harm or neglect* or trauma* or } \\
\text { i* }^{*}\end{array}$ \\
\hline & $\begin{array}{l}\text { child protection or "Foster Home Care" or "foster care" or Domestic Violence or } \\
\text { ed after child*" or "leaving care*" }\end{array}$ \\
\hline S3 & child* NEAR/3 (abuse* or cruelty or maltreat* or mal-treat* or neglect* or victimi* \\
\hline & child abuse \\
\hline & child abuse and neglect \\
\hline
\end{tabular}


Supplemental Figure 1 - Search and Extraction Process

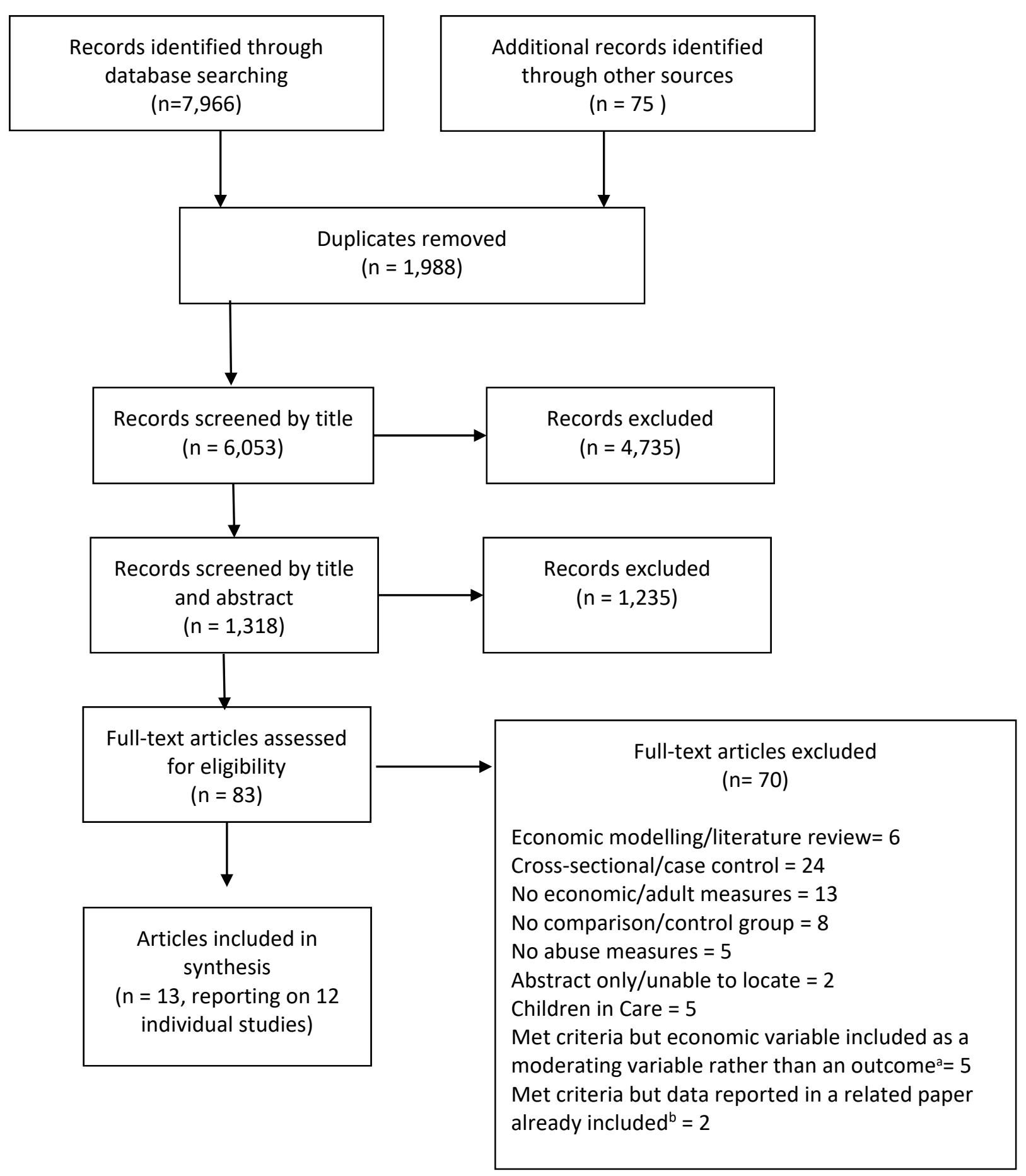




\section{${ }^{a}$ Met criteria but economic variable included as a moderating variable rather than an outcome variable}

Ben-David, V., Jonson-Reid, M., Drake, B., \& Kohl, P. L. (2015). The Association between Childhood Maltreatment Experiences and the Onset of Maltreatment Perpetration in Young Adulthood Controlling for Proximal and Distal Risk Factors. Child Abuse \& Neglect, 46, 132-141. http://doi.org/10.1016/j.chiabu.2015.01.013

Christoffersen, M. N. and Soothill, K. (2003) 'The long-term consequences of parental alcohol abuse: a cohort study of children in Denmark'. Journal of Substance Abuse Treatment , 25 (2), pp. 107-116

Horan, J., \& Widom, C. (2015). Cumulative childhood risk and adult functioning in abused and neglected children grown up. Development and Psychopathology, 27(3), 927-941.

doi:10.1017/S095457941400090X

Schilling, E. A., Aseltine, R. H. Jr., and Gore, S. (2007) 'Young Women's social and occupational development and mental health in the aftermath of child sexual abuse'. American Journal of Community Psychology, 40 (1-2), pp. 109-124

Stansfeld, S. A., Clark, C., Smuk, M., Power, C., Davidson, T., \& Rodgers, B. (2017). Childhood adversity and midlife suicidal ideation. Psychological Medicine, 47(2), 327-340.

http://doi.org/10.1017/S0033291716002336

\section{${ }^{b}$ Met criteria but data reported in a related paper already included}

McGloin, J. M., \& Widom, C. S. (2001). Resilience among abused and neglected children grown up. Development and Psychopathology, 13(4), 1021-1038

Romans, S., Martin, J., and Mullen, P. (1997) 'Childhood sexual abuse and later psychological problems: Neither necessary, sufficient nor acting alone'. Criminal Behaviour and Mental Health, 7 (4), pp. 327-338 


\section{Supplemental Table 2 - PRISMA CHECKLIST (2009)}

\begin{tabular}{|c|c|c|c|}
\hline Section/topic & \# & Checklist item & $\begin{array}{l}\text { Reported on } \\
\text { page \# }\end{array}$ \\
\hline \multicolumn{4}{|l|}{ TITLE } \\
\hline Title & 1 & Identify the report as a systematic review, meta-analysis, or both. & 1 \\
\hline \multicolumn{4}{|l|}{ ABSTRACT } \\
\hline Structured summary & 2 & $\begin{array}{l}\text { Provide a structured summary including, as applicable: background; objectives; data sources; study eligibility } \\
\text { criteria, participants, and interventions; study appraisal and synthesis methods; results; limitations; conclusions } \\
\text { and implications of key findings; systematic review registration number. }\end{array}$ & 1 \\
\hline \multicolumn{4}{|l|}{ INTRODUCTION } \\
\hline Rationale & 3 & Describe the rationale for the review in the context of what is already known. & $2-5$ \\
\hline Objectives & 4 & $\begin{array}{l}\text { Provide an explicit statement of questions being addressed with reference to participants, interventions, } \\
\text { comparisons, outcomes, and study design (PICOS). }\end{array}$ & $6-7$ \\
\hline \multicolumn{4}{|l|}{ METHODS } \\
\hline Protocol and registration & 5 & $\begin{array}{l}\text { Indicate if a review protocol exists, if and where it can be accessed (e.g., Web address), and, if available, provide } \\
\text { registration information including registration number. }\end{array}$ & 6 \\
\hline Eligibility criteria & 6 & $\begin{array}{l}\text { Specify study characteristics (e.g., PICOS, length of follow-up) and report characteristics (e.g., years considered, } \\
\text { language, publication status) used as criteria for eligibility, giving rationale. }\end{array}$ & $6-7$ \\
\hline Information sources & 7 & $\begin{array}{l}\text { Describe all information sources (e.g., databases with dates of coverage, contact with study authors to identify } \\
\text { additional studies) in the search and date last searched. }\end{array}$ & 6 \\
\hline Search & 8 & $\begin{array}{l}\text { Present full electronic search strategy for at least one database, including any limits used, such that it could be } \\
\text { repeated. }\end{array}$ & $\begin{array}{l}\text { supplemental } \\
\text { table } 1\end{array}$ \\
\hline Study selection & 9 & $\begin{array}{l}\text { State the process for selecting studies (i.e., screening, eligibility, included in systematic review, and, if applicable, } \\
\text { included in the meta-analysis). }\end{array}$ & $7-8$ \\
\hline Data collection process & 10 & $\begin{array}{l}\text { Describe method of data extraction from reports (e.g., piloted forms, independently, in duplicate) and any } \\
\text { processes for obtaining and confirming data from investigators. }\end{array}$ & $7-8$ \\
\hline Data items & 11 & $\begin{array}{l}\text { List and define all variables for which data were sought (e.g., PICOS, funding sources) and any assumptions and } \\
\text { simplifications made. }\end{array}$ & $6-9$ \\
\hline
\end{tabular}




\begin{tabular}{|c|c|c|c|}
\hline $\begin{array}{l}\text { Risk of bias in individual } \\
\text { studies }\end{array}$ & 12 & $\begin{array}{l}\text { Describe methods used for assessing risk of bias of individual studies (including specification of whether this was } \\
\text { done at the study or outcome level), and how this information is to be used in any data synthesis. }\end{array}$ & 8 \\
\hline Summary measures & 13 & State the principal summary measures (e.g., risk ratio, difference in means). & 8 \\
\hline Synthesis of results & 14 & $\begin{array}{l}\text { Describe the methods of handling data and combining results of studies, if done, including measures of } \\
\text { consistency }\left(\text { e.g., }\left.\right|^{2}\right) \text { for each meta-analysis. }\end{array}$ & $\mathrm{n} / \mathrm{a}$ \\
\hline
\end{tabular}

\begin{tabular}{|c|c|c|c|}
\hline Section/topic & $\#$ & Checklist item & Reported on page \# \\
\hline Risk of bias across studies & 15 & $\begin{array}{l}\text { Specify any assessment of risk of bias that may affect the cumulative evidence (e.g., publication bias, } \\
\text { selective reporting within studies). }\end{array}$ & $\mathrm{n} / \mathrm{a}$ \\
\hline Additional analyses & 16 & $\begin{array}{l}\text { Describe methods of additional analyses (e.g., sensitivity or subgroup analyses, meta-regression), if done, } \\
\text { indicating which were pre-specified. }\end{array}$ & $\mathrm{n} / \mathrm{a}$ \\
\hline Study selection & 17 & $\begin{array}{l}\text { Give numbers of studies screened, assessed for eligibility, and included in the review, with reasons for } \\
\text { exclusions at each stage, ideally with a flow diagram. }\end{array}$ & $\begin{array}{l}7-8 \\
\text { Supplemental Fig } \\
1\end{array}$ \\
\hline Study characteristics & 18 & $\begin{array}{l}\text { For each study, present characteristics for which data were extracted (e.g., study size, PICOS, follow-up } \\
\text { period) and provide the citations. }\end{array}$ & $\begin{array}{l}\text { Table } 1 \text { and Table } \\
2 \text { and } \\
\text { Supplemental } \\
\text { Table } 3\end{array}$ \\
\hline Risk of bias within studies & 19 & Present data on risk of bias of each study and, if available, any outcome level assessment (see item 12). & $\begin{array}{l}\text { Supplemental Table } \\
4\end{array}$ \\
\hline $\begin{array}{l}\text { Results of individual } \\
\text { studies }\end{array}$ & 20 & $\begin{array}{l}\text { For all outcomes considered (benefits or harms), present, for each study: (a) simple summary data for each } \\
\text { intervention group (b) effect estimates and confidence intervals, ideally with a forest plot. }\end{array}$ & $\begin{array}{l}\text { Table } 1 \\
\text { Table } 2\end{array}$ \\
\hline Synthesis of results & 21 & Present results of each meta-analysis done, including confidence intervals and measures of consistency. & $\begin{array}{l}\text { n/a, narrative } \\
\text { summary } 9-17\end{array}$ \\
\hline Risk of bias across studies & 22 & Present results of any assessment of risk of bias across studies (see Item 15). & $\begin{array}{l}\text { Supplemental Table } \\
4\end{array}$ \\
\hline
\end{tabular}




\begin{tabular}{|c|c|c|c|}
\hline Additional analysis & 23 & $\begin{array}{l}\text { Give results of additional analyses, if done (e.g., sensitivity or subgroup analyses, meta-regression [see } \\
\text { Item 16]). }\end{array}$ & $\mathrm{n} / \mathrm{a}$ \\
\hline \multicolumn{4}{|l|}{ DISCUSSION } \\
\hline Summary of evidence & 24 & $\begin{array}{l}\text { Summarize the main findings including the strength of evidence for each main outcome; consider their } \\
\text { relevance to key groups (e.g., healthcare providers, users, and policy makers). }\end{array}$ & $17-21$ \\
\hline Limitations & 25 & $\begin{array}{l}\text { Discuss limitations at study and outcome level (e.g., risk of bias), and at review-level (e.g., incomplete } \\
\text { retrieval of identified research, reporting bias). }\end{array}$ & $17-21$ \\
\hline Conclusions & 26 & $\begin{array}{l}\text { Provide a general interpretation of the results in the context of other evidence, and implications for future } \\
\text { research. }\end{array}$ & $21-22$ \\
\hline \multicolumn{4}{|l|}{ FUNDING } \\
\hline Funding & 27 & $\begin{array}{l}\text { Describe sources of funding for the systematic review and other support (e.g., supply of data); role of } \\
\text { funders for the systematic review. }\end{array}$ & $\begin{array}{l}\text { Title page/ } \\
\text { acknowledgements }\end{array}$ \\
\hline
\end{tabular}

From: Moher D, Liberati A, Tetzlaff J, Altman DG, The PRISMA Group (2009). Preferred Reporting Items for Systematic Reviews and Meta-Analyses: The PRISMA Statement. PLoS Med 6(7): e1000097. doi:10.1371/journal.pmed1000097

For more information, visit: www.prisma-statement.org. 
Supplemental Table 3 - Full Study Description

\begin{tabular}{|c|c|c|c|c|}
\hline & $\begin{array}{l}\text { Country, Sample Size, Study Design and } \\
\text { Follow Up Period }\end{array}$ & $\begin{array}{l}\text { Maltreatment } \\
\text { Measures }\end{array}$ & Outcome Measures & $\begin{array}{l}\text { Analysis (include controls for } \\
\text { family of origin SES) }\end{array}$ \\
\hline $\begin{array}{l}\text { Covey, Menard \& } \\
\text { Franzese (2013) }\end{array}$ & $\begin{array}{l}\text { USA ( } N=1500) \\
\text { Used prospective and retrospective data from } \\
\text { the National Youth Survey, a longitudinal } \\
\text { study based on a national probability sample } \\
\text { of individuals aged } 11-17 \text { years old in } \\
\text { 1976/1977. Participants were followed for } \\
27 y r s \text { over multiple time points (1976- 2003). }\end{array}$ & $\begin{array}{l}\text { Prospective self- } \\
\text { reported past year } \\
\text { CPA measuring at five } \\
\text { time points (aged 11- } \\
17 \text { to } 15-21 \text { ) \& ever } \\
\text { witnessing parental } \\
\text { violence as a child } \\
\text { (aged } 24-30 / 37-43 y r s \text { ) }\end{array}$ & $\begin{array}{l}\text { Net worth, } \\
\text { employment status, } \\
\text { past year personal } \\
\text { income and highest } \\
\text { grade of school } \\
\text { completed (approx } \\
\text { 36-43yrs at time of } \\
\text { measurement) }\end{array}$ & $\begin{array}{l}\text { Ordinary least squares multiple } \\
\text { regression analysis were used in } \\
\text { relation to educational } \\
\text { attainment, binary logistic } \\
\text { regression for adult employment } \\
\text { and ordinal logistic regression for } \\
\text { income and net worth. Analysis } \\
\text { included controls for urban/rural } \\
\text { status, class \& single parent } \\
\text { status. }\end{array}$ \\
\hline $\begin{array}{l}\text { Currie \& Widom } \\
(2010)\end{array}$ & $\begin{array}{l}\text { USA ( } \mathrm{N}=1575 \text { ) } \\
\text { Used a prospective cohort design. Maltreated } \\
\text { children under the age of } 11 \text { were matched } \\
\text { with a non-maltreated group on the basis of } \\
\text { age, sex, race/ethnicity, family social class, } \\
\text { date of birth, hospital of birth \& home } \\
\text { address. Participants were followed for } 36 y r s \\
\text { over } 3 \text { time points }(1967 / 71-2003 / 04)\end{array}$ & $\begin{array}{l}\text { Prospective } \\
\text { measurement using } \\
\text { court substantiated } \\
\text { cases of CPA, CSA and } \\
\text { neglect processed } \\
1967-1971 .\end{array}$ & $\begin{array}{l}\text { Having a skilled job, } \\
\text { highest grade school } \\
\text { completed at age } 29 ; \\
\text { employment status, } \\
\text { annual earnings from } \\
\text { employment at age } \\
41 .\end{array}$ & $\begin{array}{l}\text { Ordinary Least Squares (OLS) and } \\
\text { logistic regression were used to } \\
\text { compare groups with additional } \\
\text { variables added to control for } \\
\text { differences between the groups } \\
\text { in terms of family background. } \\
\text { These included: having a parents } \\
\text { in receipt of welfare, attendance } \\
\text { at Head Start, maternal } \\
\text { employment and education. } \\
\text { Estimation of models separately } \\
\text { for men and women }\end{array}$ \\
\hline $\begin{array}{l}\text { Fahy, Stansfeld, } \\
\text { Smuk, Lain, van } \\
\text { der Horst, } \\
\text { Vickerstaff \& } \\
\text { Clark (2017) }\end{array}$ & $\begin{array}{l}\text { UK }(\mathrm{N}=9,137) \\
\text { Prospective } 1958 \text { British birth cohort data was } \\
\text { used to examine associations of child neglect } \\
\text { and abuse with outcome in later adulthood. }\end{array}$ & $\begin{array}{l}\text { Retrospective self- } \\
\text { reported abuse } \\
\text { (combined parental } \\
\text { CPA and CSA) [ } 45 \\
\text { years] }\end{array}$ & $\begin{array}{l}\text { Labour participation: } \\
\text { full-time work, part- } \\
\text { time work, } \\
\text { unemployed, } \\
\text { permanent sickness } \\
\text { or disability, retired, }\end{array}$ & $\begin{array}{l}\text { Used multinomial logistic } \\
\text { regression adjusting for gender, } \\
\text { mental health in childhood, } \\
\text { educational disengagement } \\
\text { adulthood mental and physical } \\
\text { health, qualifications, and social }\end{array}$ \\
\hline
\end{tabular}




\begin{tabular}{|c|c|c|c|c|}
\hline & $\begin{array}{l}\text { Participants were followed from birth for } 55 \\
\text { years over multiple time points (1958-2013) }\end{array}$ & $\begin{array}{l}\text { Prospective neglect } \\
\text { based on reports that } \\
\text { child appeared } \\
\text { "scruffy or underfed" } \\
\text { (7 \& 11yrs) }\end{array}$ & $\begin{array}{l}\text { homemaker or other } \\
\text { (55yrs) }\end{array}$ & $\begin{array}{l}\text { class. Included measures of } \\
\text { family SES including paternal } \\
\text { socio-economic position and } \\
\text { cumulative variable indicating the } \\
\text { number of times during } \\
\text { childhood the cohort member } \\
\text { belonged to a manual social class. } \\
\text { However, this was treated as a } \\
\text { separate independent variable } \\
\text { and outcome and was not } \\
\text { controlled for in analysis. }\end{array}$ \\
\hline $\begin{array}{l}\text { Fergusson, } \\
\text { McLeod \& } \\
\text { Horwood (2013) }\end{array}$ & $\begin{array}{l}\text { New Zealand ( } \mathrm{N}=987) \\
\text { Used data from a prospective birth cohort } \\
\text { study, the Christchurch Health and } \\
\text { Development Study (CHDS), which followed } \\
\text { participants for 30yrs over multiple time } \\
\text { points (1977-2007) }\end{array}$ & $\begin{array}{l}\text { Retrospective self- } \\
\text { reported CSA prior to } \\
\text { age } 16 \text { (ages } 18 \text { and } \\
21 \mathrm{yrs} \text { ) }\end{array}$ & $\begin{array}{l}\text { Annual gross } \\
\text { personal income } \\
\text { (age 30yrs); receipt } \\
\text { of a government } \\
\text { social welfare when } \\
\text { aged } 25-30 y r s \text { l left } \\
\text { school without } \\
\text { qualifications by age } \\
21 .\end{array}$ & $\begin{array}{l}\text { Used generalized linear } \\
\text { regression model incorporating a } \\
\text { range of covariates including } \\
\text { measures of family functioning } \\
\text { and child factors. Controlled for } \\
\text { maternal age and education, } \\
\text { family living standards and family } \\
\text { income. }\end{array}$ \\
\hline $\begin{array}{l}\text { Harkonmäki, } \\
\text { Korkeila, } \\
\text { Vahtera, } \\
\text { Kivimäki, } \\
\text { Suominen, } \\
\text { Sillanmäki \& } \\
\text { Koskenvuo } \\
\text { (2007) }\end{array}$ & $\begin{array}{l}\text { Finland ( } \mathrm{N}=8817) \\
\text { Data were derived from the Health and Social } \\
\text { Support Study, a longitudinal study based on a } \\
\text { representative sample of Finnish adult } 1^{\text {st }} \\
\text { surveyed in } 1998 \text { and followed up } 5 \text { years later } \\
(2003) \text {. }\end{array}$ & $\begin{array}{l}\text { Retrospective self- } \\
\text { reported exposure to } \\
6 \text { childhood } \\
\text { adversities at any time } \\
\text { during childhood: } \\
\text { included serious } \\
\text { family conflict and } \\
\text { frequent fear of a } \\
\text { family member (aged } \\
40-54 \text { ) }\end{array}$ & $\begin{array}{l}\text { Disability retirement } \\
\text { (aged 45-59) }\end{array}$ & $\begin{array}{l}\text { Binary response logistic } \\
\text { regression models with additional } \\
\text { adjustments for adult risk factors. } \\
\text { Controlled for adult risk factors } \\
\text { but no control of family of origin } \\
\text { SES/income etc. }\end{array}$ \\
\hline
\end{tabular}




\begin{tabular}{|c|c|c|c|c|}
\hline $\begin{array}{l}\text { Lund, } \\
\text { Andersen,Windin } \\
\text { g, Biering \& } \\
\text { Labriola (2013) }\end{array}$ & $\begin{array}{l}\text { Denmark }(\mathrm{N}=3,068) \\
\text { A prospective study based on data from a } \\
\text { cohort of children born in } 1989 \text { who } \\
\text { completed baseline questionnaires in } 2004 \text {. } \\
\text { Participants were followed for } 6 / 7 y \text { rs over } 2 \\
\text { time points }(2004-2010 / 11)\end{array}$ & $\begin{array}{l}\text { Retrospective self- } \\
\text { reported negative life } \\
\text { events (NLE) assessed } \\
\text { using } 6 \text { items, } \\
\text { including being } \\
\text { abused by someone } \\
\text { known to the subject } \\
\text { (age } 14-15 y \text { rs) }\end{array}$ & $\begin{array}{l}\text { Labour market } \\
\text { participation (LMP), } \\
\text { defined according to } \\
\text { degree of receiving } \\
\text { social benefits over } \\
\text { one year (21-22yrs) }\end{array}$ & $\begin{array}{l}\text { Logistic regression which } \\
\text { controlled for childhood SES } \\
\text { together with school grades, } \\
\text { educational plans, vocational } \\
\text { expectations and self-rated } \\
\text { health. }\end{array}$ \\
\hline $\begin{array}{l}\text { Mersky \& } \\
\text { Topzites (2010) }\end{array}$ & $\begin{array}{l}\text { USA (N=@1400) } \\
\text { Used prospective data from the Chicago } \\
\text { Longitudinal Study, a panel study of pre- } \\
\text { school minority children from economically } \\
\text { disadvantaged areas. Participants were } \\
\text { followed for 20yrs over multiple time points } \\
\text { (1983/1984- 2003/04) }\end{array}$ & $\begin{array}{l}\text { Prospective } \\
\text { measurement using } \\
\text { court records and } \\
\text { referrals to child } \\
\text { protection services } \\
\text { indicative of } \\
\text { maltreatment (aged 0- } \\
17 y r s)\end{array}$ & $\begin{array}{l}\text { Regular } \\
\text { employment/college } \\
\text { attendance, above } \\
\text { average income over } \\
\text { 2yrs, high school } \\
\text { completion and } \\
\text { attendance at } 4 \text { year } \\
\text { college (aged 18-24). }\end{array}$ & $\begin{array}{l}\text { Analysis involved multivariate } \\
\text { probit regression with marginal } \\
\text { effect coefficients and controlled } \\
\text { for: the participants' mothers not } \\
\text { being employed/ not completing } \\
\text { high school; family size; single- } \\
\text { parent status; benefit receipt; } \\
\text { and neighbourhood. }\end{array}$ \\
\hline $\begin{array}{l}\text { Mullen, Martin, } \\
\text { Anderson \& } \\
\text { Romans (1994); } \\
\text { Mullen, Martin, } \\
\text { Anderson, } \\
\text { Romans \& } \\
\text { Herbison (1996) }\end{array}$ & $\begin{array}{l}\text { New Zealand } \\
N=492 \text { (Mullen et al. 1994, Romans et al. } \\
\text { 1997) } \\
\mathrm{N}=102 \text { (Mullen et al. (1997) } \\
\text { A retrospective comparison of a maltreated } \\
\text { and non-maltreated based on a subset of } \\
\text { women who participated in random survey in } \\
\text { 1998 and who were re-interviewed after } 14 \\
\text { months. }\end{array}$ & $\begin{array}{l}\text { Retrospective self- } \\
\text { reported childhood } \\
\text { sexual, physical \& } \\
\text { emotional abuse } \\
\text { before age } 16 \text {, no age } \\
\text { given for time of } \\
\text { measurement, } \\
\text { (sample adult females } \\
\text { up under } 65 \text { ) }\end{array}$ & $\begin{array}{l}\text { Self-reported adult } \\
\text { SES (estimated from } \\
\text { current occupation } \\
\text { \&/or partner's), no } \\
\text { age given for time of } \\
\text { measurement } \\
\text { (sample adult } \\
\text { females under 65) }\end{array}$ & $\begin{array}{l}\text { Mullen et al. (1994) and Romans } \\
\text { et al. (1997) used logistic } \\
\text { regression to test the importance } \\
\text { of CSA on outcomes, in } \\
\text { combination with relevant risk } \\
\text { factors (including CPA and EA) } \\
\text { and social background variables. } \\
\text { Analyses controlled for SES of } \\
\text { family of origin (derived from } \\
\text { parent's occupation). Mullen et } \\
\text { al. (1996) focused on a subset of } \\
\text { the most severe forms of } \\
\text { reported abuse and } \\
\text { differentiated between CSA, CPA } \\
\text { and EA. }\end{array}$ \\
\hline
\end{tabular}




\begin{tabular}{|c|c|c|c|c|}
\hline $\begin{array}{l}\text { Pinto Pereira, Li } \\
\text { \& Power (2017) }\end{array}$ & $\begin{array}{l}\text { UK }(\mathrm{N}=8,076) \\
\text { Prospective } 1958 \text { British birth cohort data was } \\
\text { used to examine associations of child neglect } \\
\text { and abuse with adult outcomes at age } 50 \\
\text { years. }\end{array}$ & $\begin{array}{l}\text { Prospective neglect } \\
\text { measure based on } \\
\text { parental interviews } \\
\text { and questionnaires } \\
\text { completed by teachers } \\
\text { (7-11yrs). } \\
\text { Retrospective self- } \\
\text { reported emotional } \\
\text { neglect, sexual, } \\
\text { physical and } \\
\text { psychological abuse } \\
\text { and witnessing } \\
\text { domestic violence } \\
\text { (45yrs). }\end{array}$ & $\begin{array}{l}\text { Measured economic } \\
\text { activity at age 23yrs } \\
\text { and 50yrs [long-term } \\
\text { sickness absence } \\
\text { (LTS), not in } \\
\text { employment, } \\
\text { education, or } \\
\text { training (NEET)]; lack } \\
\text { of assets (home } \\
\text { ownership) and } \\
\text { receipt of income- } \\
\text { related support at } \\
\text { age 50yrs; social } \\
\text { mobility from 0- } \\
\text { 50yrs and 23-50ys. }\end{array}$ & $\begin{array}{l}\text { Logistic regression used to assess } \\
\text { associations of each type of } \\
\text { maltreatment with adult } \\
\text { outcomes as well as the } \\
\text { interaction between each type of } \\
\text { maltreatment and sex. A range of } \\
\text { covariates were identified as } \\
\text { early-life factors that influence } \\
\text { socioeconomic destinations were } \\
\text { included: socioeconomic } \\
\text { background, parental education, } \\
\text { household amenities, crowding, } \\
\text { and tenure, maternal age at birth, } \\
\text { birth weight, birth order and poor } \\
\text { child health. }\end{array}$ \\
\hline $\begin{array}{l}\text { Strøm, Thoresen, } \\
\text { Wentzel-Larsena, } \\
\text { Hjemdal, Lien \& } \\
\text { Dyb (2013) }\end{array}$ & $\begin{array}{l}\text { Norway }(\mathrm{N}=11,874) \\
\text { A prospective study which } 1^{\text {st }} \text { surveyed young } \\
\text { people in junior high in six Norwegian counties } \\
\text { in } 2000 \text { and followed up 8yrs later (2008). }\end{array}$ & $\begin{array}{l}\text { Retrospective self- } \\
\text { reported experiences } \\
\text { of CSA, CPA and } \\
\text { bullying in school in } \\
\text { the past } 12 \text { months } \\
\text { (measured at age 15- } \\
\text { 16yrs) }\end{array}$ & $\begin{array}{l}\text { Work participation } \\
\text { during } 2008 \\
\text { (participants aged } \\
21-24 y r s \text { ) }\end{array}$ & $\begin{array}{l}\text { Proportional odds and ordinal } \\
\text { logistic regression analyses with } \\
\text { high school completion as a } \\
\text { mediating variable. It included } \\
\text { controls for: perceived financial } \\
\text { situation during childhood, } \\
\text { parents' educational level and } \\
\text { employment. }\end{array}$ \\
\hline $\begin{array}{l}\text { Tanaka, } \\
\text { Jamieson, Duku, } \\
\text { Boyle \& } \\
\text { MacMillan (2011) }\end{array}$ & $\begin{array}{l}\text { Canada }(\mathrm{N}=1,893) \\
\text { A prospective study based on data from the } \\
\text { Ontario Child Health Study which collected } \\
\text { baseline data from children aged } 4-16 \text { yrs in }\end{array}$ & $\begin{array}{l}\text { Retrospective self- } \\
\text { reported CPA \& CSA } \\
\text { before the age of } 16 \\
\text { measured using short } \\
\text { form of the Childhood } \\
\text { Experiences Violence }\end{array}$ & $\begin{array}{l}\text { Employed in past } 12 \\
\text { months, annual } \\
\text { personal income (for } \\
\text { those employed), no } \\
\text { of years of education }\end{array}$ & $\begin{array}{l}\text { Multilevel regression analyses } \\
\text { comparing maltreated and non- } \\
\text { maltreated group and examining } \\
\text { the mediating role of education, } \\
\text { physical health and mental } \\
\text { health. Analyses included }\end{array}$ \\
\hline
\end{tabular}




\begin{tabular}{|l|l|l|l|l|}
\hline & $\begin{array}{l}\text { 1983. Participants were followed for 18yrs } \\
\text { over } 3 \text { time points (1983/1987/2000-01). }\end{array}$ & $\begin{array}{l}\text { Questionnaire (aged } \\
21-25 \text { when } \\
\text { measured) }\end{array}$ & $\begin{array}{l}\text { aged 21-25 years } \\
\text { when measured) }\end{array}$ & $\begin{array}{l}\text { controls for: family income, } \\
\text { parental years of education, \& } \\
\text { occupational prestige. It also } \\
\text { include testing for the interaction } \\
\text { effects of gender. }\end{array}$ \\
\hline $\begin{array}{l}\text { Vinnerljung, } \\
\text { Sundell, Löfholm, } \\
\text { \& Humlesjö } \\
\text { (2006) }\end{array}$ & $\begin{array}{l}\text { Sweden (N=2,232) } \\
\text { Retrospective cohort study comparing } \\
\text { children known to child protection authorities } \\
\text { who were born in Stockholm1968-1975 with } \\
\text { general population peers using national } \\
\text { register data. Outcomes were measured at } \\
\text { multiple time points when participants were } \\
\text { aged 21-25yrs (1993/2000-01) }\end{array}$ & $\begin{array}{l}\text { Prospective } \\
\text { measurement using } \\
\text { records of children } \\
\text { known to child } \\
\text { protection authorities } \\
\text { (cases resulting in } \\
\text { investigation/service } \\
\text { provision were taken } \\
\text { to be substantiated) }\end{array}$ & $\begin{array}{l}\text { Number of months } \\
\text { subjects received } \\
\text { welfare during year } \\
\text { they turned 25 } \\
\text { (national register } \\
\text { data) }\end{array}$ & $\begin{array}{l}\text { Multiple regression analyses with } \\
\text { forced entry. Did not control for } \\
\text { parental SES but controlled for } \\
\text { gender, having a teenage mother, } \\
\text { and immigrant background }\end{array}$ \\
\hline
\end{tabular}


Supplementary Table 3 - Assessment of Study Quality

\begin{tabular}{|c|c|c|c|c|c|c|c|c|c|c|c|}
\hline Study & $\begin{array}{l}\text { Represent- } \\
\text { ativeness } \\
\text { of the } \\
\text { population }\end{array}$ & $\begin{array}{l}\text { Ascertain } \\
\text { ment of } \\
\text { exposure } \\
\text { to child } \\
\text { abuse \& } \\
\text { neglect }\end{array}$ & $\begin{array}{l}\text { Selection } \\
\text { of the } \\
\text { non- } \\
\text { exposed } \\
\text { cohort/co } \\
\text { ntrols }\end{array}$ & $\begin{array}{l}\text { Assessme } \\
\text { nt of child } \\
\text { abuse \& } \\
\text { neglect }\end{array}$ & $\begin{array}{l}\text { Case } \\
\text { definition } \\
\text { for child } \\
\text { abuse \& } \\
\text { neglect }\end{array}$ & $\begin{array}{l}\text { Assessme } \\
\text { nt of } \\
\text { outcome }\end{array}$ & $\begin{array}{l}\text { Adequacy } \\
\text { of follow- } \\
\text { up of } \\
\text { cohorts }\end{array}$ & $\begin{array}{l}\text { Appropriate } \\
\text { statistical } \\
\text { analysis }\end{array}$ & $\begin{array}{l}\text { Appropriate } \\
\text { methods to } \\
\text { control } \\
\text { confounding }\end{array}$ & $\begin{array}{l}\text { Source } \\
\text { of } \\
\text { funding } \\
\text { declared }\end{array}$ & $\begin{array}{l}\text { Total } \\
\text { Quality } \\
\text { Score }\end{array}$ \\
\hline $\begin{array}{l}\text { Covey, Menard \& } \\
\text { Franzese (2013) }\end{array}$ & 7 & & & & & & & & & & 7 \\
\hline $\begin{array}{l}\text { Currie \& Widom } \\
\text { (2010) }\end{array}$ & 负 & 交 & $\hat{\lambda}$ & 交 & 卖 & & & 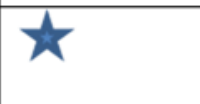 & 7 & & 8 \\
\hline $\begin{array}{l}\text { Fahy, Stansfeld, } \\
\text { Smuk, Lain, van der } \\
\text { Horst, Vickerstaff \& } \\
\text { Clark (2017) }\end{array}$ & t & 交 & $\widehat{\lambda}$ & & & & & & & & 5 \\
\hline $\begin{array}{l}\text { Fergusson, McLeod \& } \\
\text { Horwood (2013) }\end{array}$ & t & & $\lambda$ & & & & & 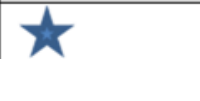 & & & 5 \\
\hline $\begin{array}{l}\text { Harkonmäki, } \\
\text { Korkeila, Vahtera, } \\
\text { Kivimäki, Suominen, } \\
\text { Sillanmäki \& } \\
\text { Koskenvuo (2007) }\end{array}$ & $\hat{\gamma}$ & & $\hat{x}$ & & & & 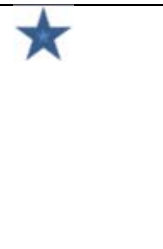 & 1 & & 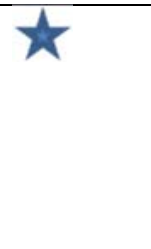 & 5 \\
\hline $\begin{array}{l}\text { Lund, } \\
\text { Andersen,Winding, } \\
\text { Biering \& Labriola } \\
\text { (2013) }\end{array}$ & 久 & & t & & & t & $\widehat{t}$ & $\hat{\lambda}$ & 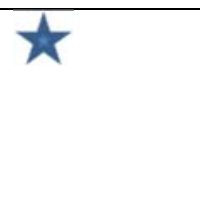 & th & 7 \\
\hline
\end{tabular}




\begin{tabular}{|c|c|c|c|c|c|c|c|c|c|c|c|}
\hline $\begin{array}{l}\text { Mersky \& Topzites } \\
\text { (2010) }\end{array}$ & 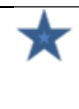 & & 久 & $\grave{\lambda}$ & $\grave{\lambda}$ & $\not \wedge$ & 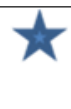 & $\boldsymbol{\lambda}$ & $\boldsymbol{t}$ & 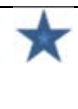 & 9 \\
\hline $\begin{array}{l}\text { Mullen, Martin, } \\
\text { Anderson \& Romans } \\
\text { (1994); Mullen, } \\
\text { Martin, Anderson, } \\
\text { Romans \& Herbison } \\
\text { (1996) }\end{array}$ & & & ২ & & & & $\not \lambda$ & 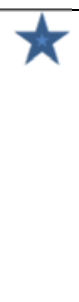 & $\boldsymbol{t}$ & $\downarrow \backslash$ & 5 \\
\hline $\begin{array}{l}\text { Strøm, Thoresen, } \\
\text { Wentzel-Larsena, } \\
\text { Hjemdal, Lien \& Dyb } \\
\text { (2013) }\end{array}$ & ' & & 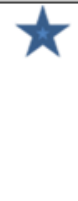 & & & 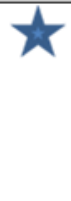 & $\boldsymbol{k}$ & $\boldsymbol{\lambda}$ & $\boldsymbol{t}$ & 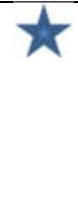 & 7 \\
\hline $\begin{array}{l}\text { Vinnerljung, Sundell, } \\
\text { Löfholm, \& Humlesjö } \\
\text { (2006) }\end{array}$ & 入 & & ২ & & & & & 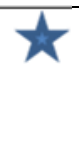 & t & ㄱ & 5 \\
\hline
\end{tabular}


